\title{
Another Look at the Grace Creek \#1 Site in Gregg County, Texas, as Seen Through Ceramic Analysis
}

Timothy K. Perttula

Heritage Research Center, Stephen F. Austin State University

Follow this and additional works at: https://scholarworks.sfasu.edu/ita

Part of the American Material Culture Commons, Archaeological Anthropology Commons, Environmental Studies Commons, Other American Studies Commons, Other Arts and Humanities Commons, Other History of Art, Architecture, and Archaeology Commons, and the United States History Commons

Tell us how this article helped you.

This Article is brought to you for free and open access by the Center for Regional Heritage Research at SFA ScholarWorks. It has been accepted for inclusion in Index of Texas Archaeology: Open Access Gray Literature from the Lone Star State by an authorized editor of SFA ScholarWorks. For more information, please contact cdsscholarworks@sfasu.edu. 
Another Look at the Grace Creek \#1 Site in Gregg County, Texas, as Seen Through Ceramic Analysis

\section{Creative Commons License}

\section{(c) (1) (8)}

This work is licensed under a Creative Commons Attribution-NonCommercial 4.0 International License 


\title{
Another Look at the Grace Creek \#1 Site in Gregg County, Texas, as Seen Through Ceramic Analysis
}

\author{
Timothy K. Pertula
}

\section{INTRODUCTION}

The purpose of this article is to present archeological findings obtained from a re-examination of the ceramic sherds from the Grace Creek \#1 site (41GG33). The Grace Creek site has been identified as having an early Caddo component by Jones (1957), one that was contemporaneous with the Caddo occupation at the George C. Davis site (Newell and Krieger 1949; Story 2000). Story (2000:Figure 5 and Table 2), in fact, identifies Grace Creek \#1 as a "modest Alto-phase habitation site." This re-examination was occasioned by ongoing studies of the Early Caddo ceramics from the ca. A.D. 970-1260 Boxed Springs mound center (Perttula 2011), and the opportunity thus presented to compare the Boxed Springs ceramic assemblage with the Grace Creek \#l site.

\section{BACKGROUND TO THE CURRENT ANALYSES}

The Grace Creek \#1 site was situated on a natural alluvial rise on the east side of Grace Creek, about $0.4 \mathrm{~km}$ north of its confluence with the Sabine River. On the north side of the site was an abandoned Sabine River lake bed, while to the south was an old channel, as well as a channel lake (Muddy Lake), of the Sabine River. Jones divided the site into three areas (A, B, and C); a midden deposit was apparently located in Area B on the central part of the rise (Jones 1957:Figure 49).

Buddy Calvin Jones identified and worked at the Grace Creck \#1 site between 1954 and 1956, while the site was being destroyed for the construction of an earthen dike along Grace Creek and the Sabine River (Jones 1957:201). In addition to the extensive surface collection of projectile points, lithic tools, and ceramic sherds he found there, in areas A-C (Jones 1957:Figure 49), Jones also conducted limited excavations in areas where apparently organically-stained soil and possible feature stains were noted on the scraped surface of the site. In these excavations, he documented midden deposits, a flexed burial in the midden deposits in Area B, two pit features in this area (Pit A and Feature 3), and several small (ca. $10 \mathrm{~cm}$ in diameter) post holes in Area C. Jones' (1957:Figure 49) map of the site did not indicate the location of the excavations in Area C, but Jones (1957:205) suggested that aboriginal houses were likely present here.

A substantial sample of ceranic sherds $(n=593)$ were collected by Jones $(1957: 206-210)$ from the Grace Creek \#1 site, almost all thought to be associated with an apparently early Caddo occupation on the rise, along with several baked clay balls, a possible pottery spoon, and the stem of a Red River longstemmed pipc. Several varieties of Red River long-stemmed pipes were used between ca. A.D. 800/8501400 (see Hoffman 1967), but no information was provided by Jones on the one from this site that would have allowed its classification and helped establish the site's temporal affiliation.

\section{NEW ANALYSES OF THE CERAMIC SHERDS FROM THE SITE}

The ceramic sherd collection from the Grace Creek $\# 1$ site is curated at the Gregg County Historical Museum in Longview, Texas. The assemblage is larger than originally reported by Jones (1957), as there are 1827 plain and decorated sherds in the collection, as well as two pieces of daub and a clay object. 


\section{Decorated Sherds}

The Grace \#1 site has an assemblage of 424 decorated sherds. The majority of them $(n=343,80.8 \%$ of all the decorated sherds from the site) can be associated with the early Caddo occupation, $79(18.7 \%)$ are from a Late Caddo occupation that was concentrated in Area B, and there are two $(0.5 \%)$ distinctive Woodland period sherds.

\section{Late Woodland decorated sherds}

There are two contemporaneous grog-tempered Woodland period (ca. A.D. 400-800) sherds in the Grace Creek $\# 1$ site collection. They are a Marksville Stamped, var. Troyville body sherd and a Marksville Incised, var. Yokena body sherd (Figure 1a); both are from vessels fired in a reducing environment, and cooled in the open air (cf. Teltser 1993:Figure 2g). The var. Troyville stamped sherd has broad parallel incised lines that define zones of rocker stamping (Brown 1998:33). The Marksville Incised, var. Yokena sherd also has broad and widely spaced incised lines, but these lines are arranged in both curvilinear and rectilinear patterns (cf. Brown 1998:16).

Both Marksville Incised, var. Yokena and Marksville Stamped, var. Troyville are common types and varieties at the well-dated Fredericks site (16NA2) along the Red River in Natchitoches Parish, Louisi-

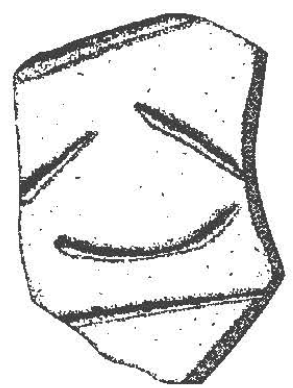

a

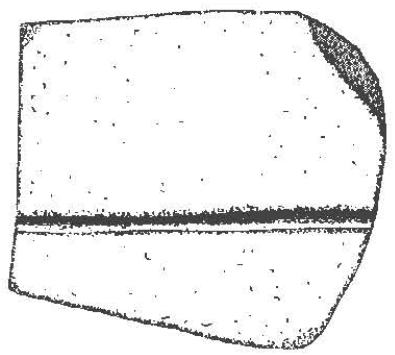

$\mathrm{c}$

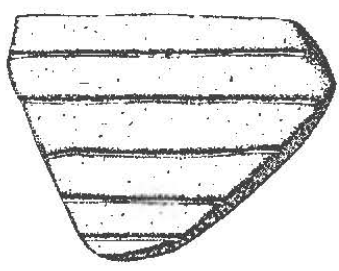

e
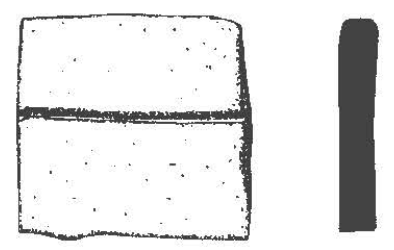

b

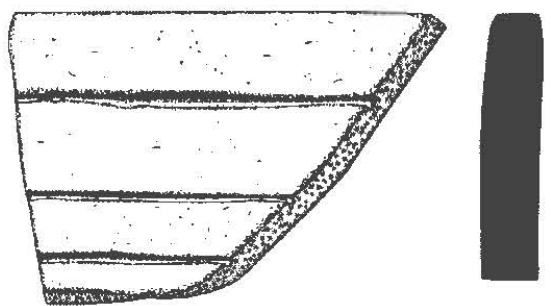

d

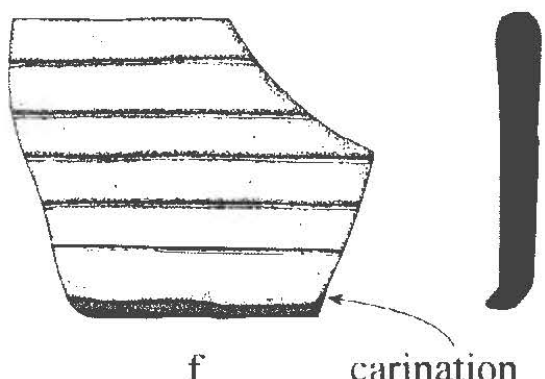

Figure 1. Marksville Incised, var. Yokena and horizontal incised rim sherds from the Grace Creek \# I site: a, Marksville Incised, var. Yokena; b, e-f, horizontal incised rim sherds; $\mathrm{c}$-d, horizontal incised line, broad line. 
ana (Girard 2000:Table 4). Calibrated radiocarbon dates establish the age of the Fredericks occupation at between A.D. 400-800 (Girard 2000:Figure 12 and Table 3).

Marksville Stamped sherds from a number of different varieties, including var. Manny, var. Marksville, and var. Troyville, are present in several sites in the Sabine, Sulphur, and Big Cypress drainage basins in East Texas, sometimes with some frequency (Story 1990:246-247, 278-279, 286, 303, and 311). Examples of var. Troyville ceramic sherds occur in radiocarbon-dated Late Woodland (ca. A.D. 400-800) contexts at sites along the Red River in northwestern Louisiana (Girard 1998, 2000:66, 82). Lec (2007:5 and Table 1) reports that Marksville Stamped, var. Troyville ceramics occur at the Troyville site in features with 2 sigma calibrated radiocarbon dates that range from A.D 640-880, and Marksville Stamped, var. Troyville, among other types, occur in mound fill at the Gold Mine site (16RI13) that has been dated to the A.D. 775-874 interval (McGimsey 2004). In East Texas, Marksville Stamped, var. Troyville sherds are rarely seen in local Woodland period sites or components in the Sabine River or the Neches-Angelina and Attoyac river basins (Story 1990; Middlcbrook 2010; Perttula 2008; Walters and Perttula 2010).

\section{Early Caddo Period decorated sherds}

The decorated sherds from this early Caddo component are dominated by utility wares, particularly sherds from vessels decorated with incised lines (Table 1 ). The utility wares comprise $90 \%$ of the decorated rims and $95.2 \%$ of the decorated body sherds. The fine wares - all from engraved vessels - only account for $6.4 \%$ of the total number of decorated sherds in the Grace Creek \#1 site, indicating the site was occupied during a time when engraved fine wares were not in common use, or were not commonly accessible to the Caddo peoples that lived there.

Table 1. Decorated sherds in the Grace Creek \#1 Site Early Caddo ceramic assemblage.

\begin{tabular}{llll}
\hline Wares and & Rim & Body & N \\
Decorative Methods & & & \\
\hline Utility ware & & & \\
\hline & 72 & 156 & 228 \\
Incised & 4 & 22 & 26 \\
Incised-Punctated & 5 & 19 & 24 \\
Punctated & 3 & 18 & 21 \\
Incised-Impressed Triangles & 2 & 8 & 10 \\
Ridged-Pinchcd & 1 & 6 & 2 \\
Impressed Triangles & - & 2 & 2 \\
Incised-Ridgcd-Pinched & 2 & - & 1 \\
Lip Notched & - & 1 & \\
Band Punctated & & & 22 \\
Fine ware & & & \\
\hline & & 12 & 343 \\
Engraved & 10 & 244 & \\
\hline Totals & & & \\
\hline
\end{tabular}


The incised sherds from the Grace Creek \#1 site account for almost $67 \%$ of the decorated sherd assemblage, including more than $72 \%$ of the rim sherds (see Table 1). Vessels with incised decorations are clearly the predominant decorative class, both among the utility wares as well as among the entire decorated sherd assemblage. The majority of the incised sherds-especially the rim sherds - are from vessels with one to many horizontal incised lincs on the rim of bowls (Table 2). All of the Grace Creek \#1 site incised sherds are probably from different varieties of post-A.D. 700-850 Coles Creek lncised vessels (see Brown 1998: Phillips 1970), although some could also be from Davis Incised vessels (Suhm and Jelks 1962:35 and Plate 18). It is likely that vessels of both types were made locally, based on chemical analysis of the paste from Coles Creek Incised vessel sherds found in East Texas (Walters and Perttula 2010:37 and Figure 3).

Table 2. Horizontal Incised sherds.

\begin{tabular}{|c|c|c|c|}
\hline Decorative element & $\operatorname{Rim}$ & Body & $\mathrm{N}$ \\
\hline $\begin{array}{l}\text { Incised lip line only (Coles } \\
\text { Creek Incised) }\end{array}$ & 2 & - & 2 \\
\hline $\begin{array}{l}\text { single horizontal line midway } \\
\text { down rim* }\end{array}$ & 3 & - & 3 \\
\hline single horizontal line & 10 & 1 & 11 \\
\hline single horizontal line below lip & 1 & - & 1 \\
\hline single broad line & 1 & 1 & 2 \\
\hline multiple broad lines* & 2 & 1 & 3 \\
\hline multiple broad lines & 3 & - & 3 \\
\hline multiple widely-spaced lines* & 3 & 1 & 4 \\
\hline multiple widely-spaced lincs & 20 & 4 & 24 \\
\hline multiple closely-spaced lines & 7 & 2 & 9 \\
\hline multiplc closely-spaced lines* & 3 & - & 3 \\
\hline multiple very closely-spaced lines** & 12 & - & 12 \\
\hline Totals & 67 & 10 & 77 \\
\hline
\end{tabular}

Those sherds with a single horizontal incised line on the rim, whether that line is overhanging or not, may be from Coles Creek Incised, var. Stoner or var. Phillips (Brown 1998:8), mainly the latter, since few $(18 \%)$ of these have overhanging lines. Those sherds that have closely or very-closely spaced horizontal incised lines (see Figures 2 and 3) are probably from Coles Creek Incised, var. Mott (those with overhanging lines), or var. Hardy or var. Blakely (those varieties without overhanging lines) (Brown 1998:9). Almost $63 \%$ of the sherds with closely-spaced or very-closely-spaced horizontal lines also have overhanging lines. 


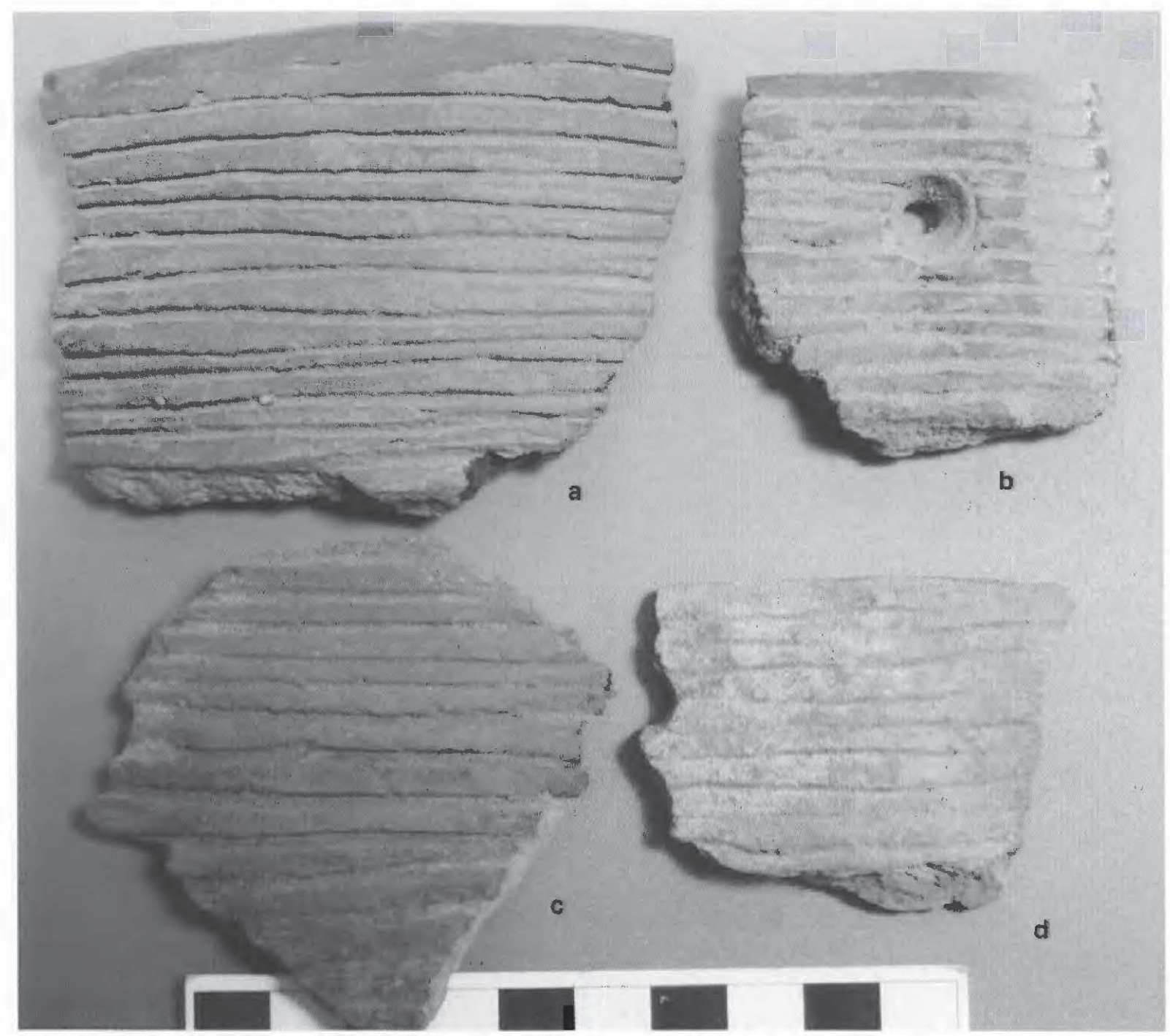

Figure 2. Closely-spaced horizontal incised rim sherds: a, d, rim sherds; b, rim sherd with suspension hole; c, body sherd.

The widely-spaced and multiple broad line horizontal incised sherds (Figure 4) from the site may also be from Coles Creek Incised, var. Coles Creek, var. Hardy, or var. Blakely vessels, mainly the latter because only $21 \%$ of these sherds from the Grace Creek \#1 site have overhanging lines (see Table 2); those that do are Coles Creek Incised, var. Coles Creek sherds. Most of the Coles Creek Incised, var. Coles Creek vessel sherds from the site also have a row of impressed triangles below the lowest horizontal incised line (see below; see also Phillips 1970:70).

The other incised sherds from the Grace Creek \#1 site are dominated by body sherds with sets of parallel incised lines, ranging from closely-spaced to widely-spaced (Table 3). The orientation of these sherds is uncertain, but it is likely that they are also from horizontal incised vessels, namely from the lowermost part of the incised rim area, but missing the rim itself. About $10 \%$ of these sherds have overhanging lines, probably from Coles Creek Incised, var. Mott and var. Coles Creek. The body sherds with parallel, but not overhanging lines, may be from both Davis Incised and other varieties of Coles Creek Incised.

The rim sherds in this large group of incised sherds are from Dunkin Incised vessels (Figure 5a-c). They have chevron-shaped sets of opposed diagonal incised or diagonal incised lines on the rim itself, or perhaps from the lowermost part of the rim decoration (Figure 5d, see Suhm and Jelks 1962:Plate 19f-g). 

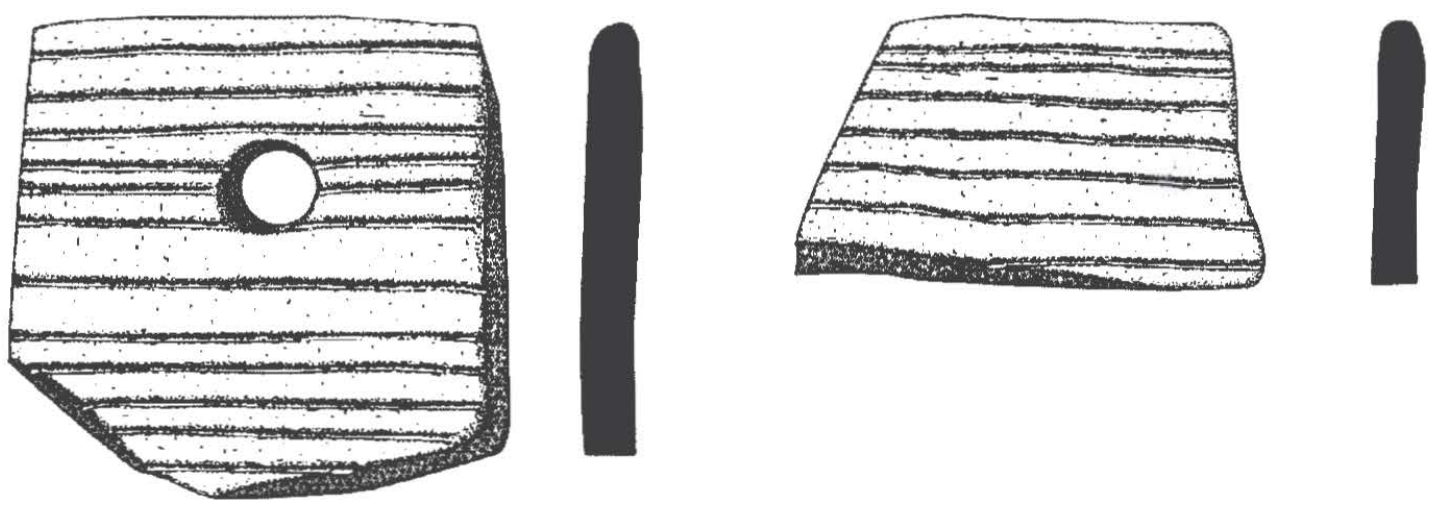

a
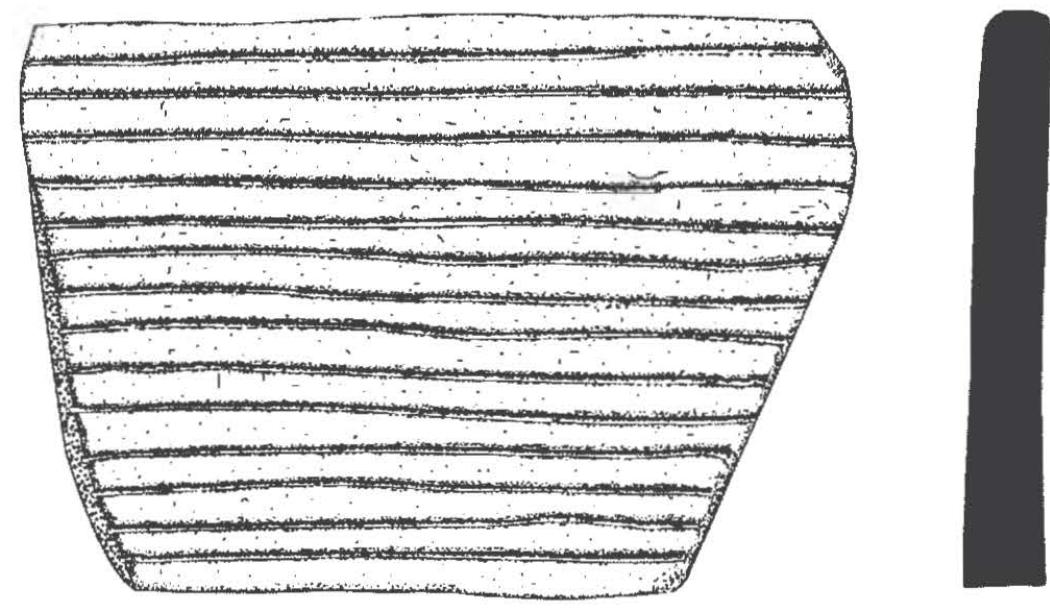

c
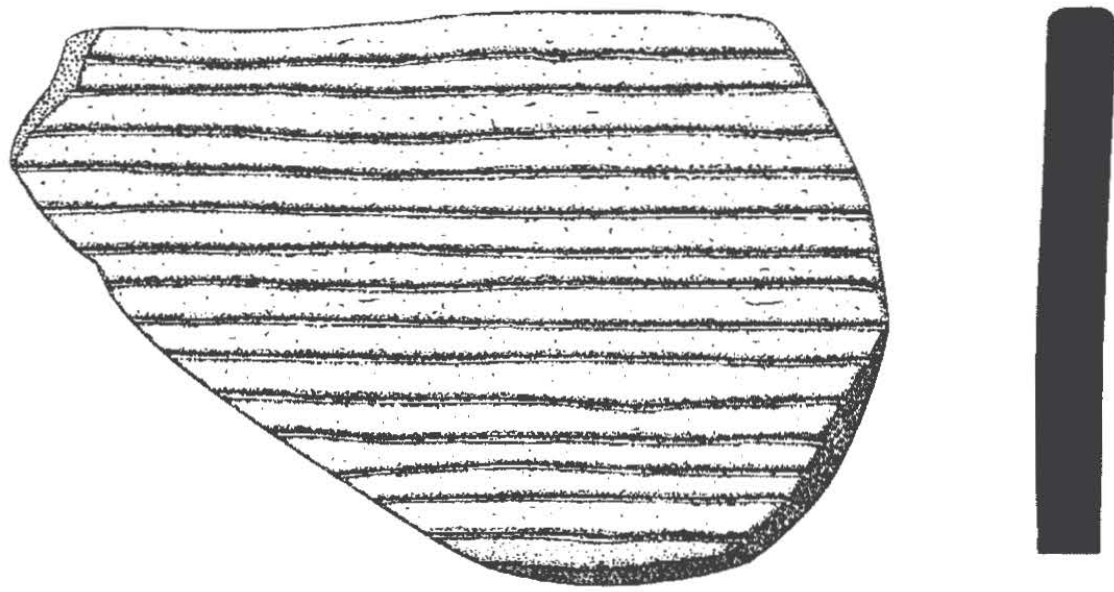

\section{d}

Figure 3. Drawings of closely-spaced horizontal incised rim sherds. 


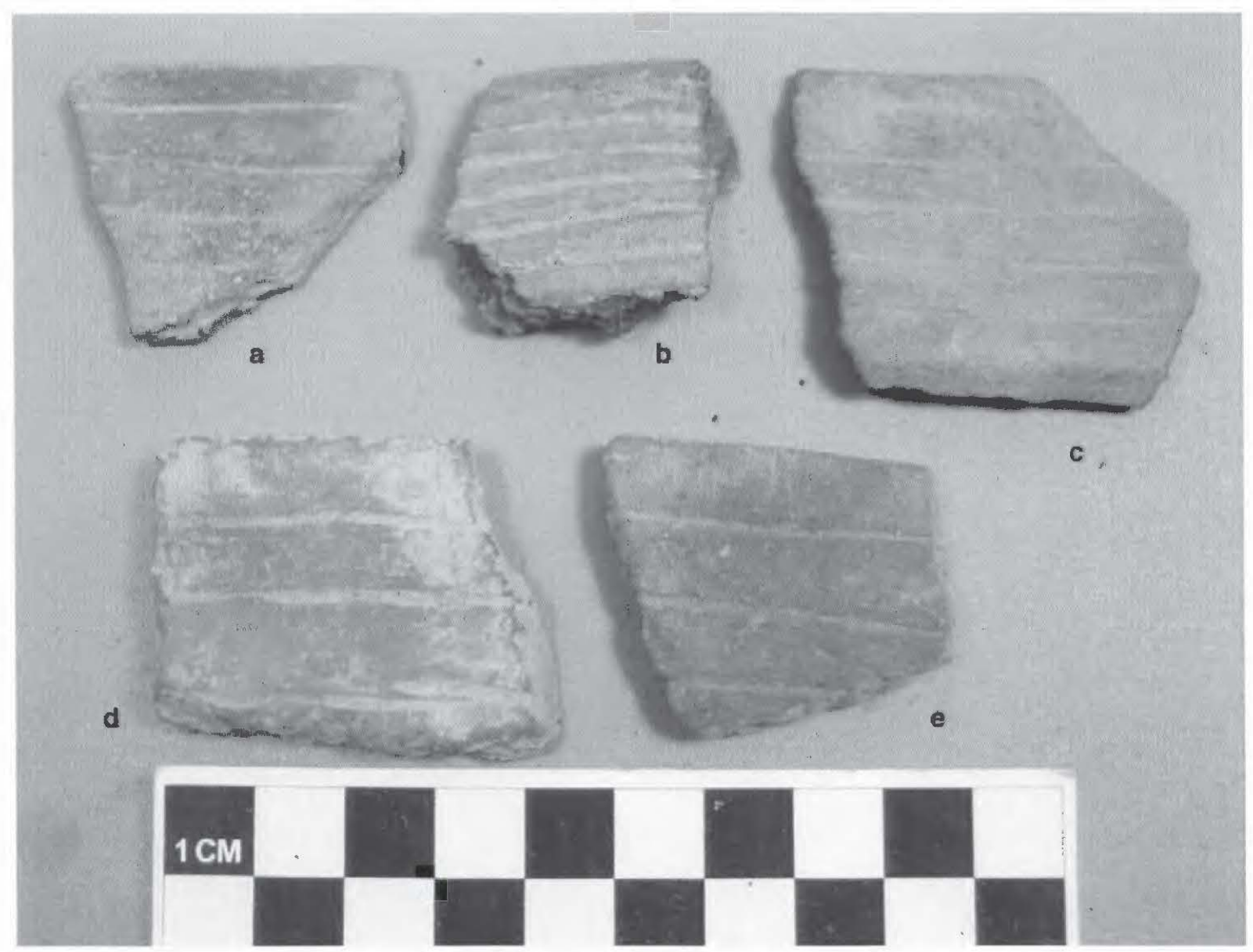

Figure 4. Widely-spaced and closely-spaced horizontal incised sherds: a, c-e, widely-spaced lines; b, closely-spaced lines.

Only $4.6 \%$ of the Table 3 incised sherds have curvilinear incised lines as the decorative element, including one sherd with curvilinear incised lines on the interior rim of a vessel (see Table 3). Four of the sherds have widely-spaced and/or broad curvilinear incised lines, perhaps indicating they are from Crockett Curvilinear Incised vessels, although this is speculative. Two other body sherds (see Figure $5 \mathrm{e}-\mathrm{f}$ ) have very closely-spaced fine curvilinear incised zones that appear to be in curvilinear zones, probably part of scroll elements. As such, they resemble the defined type and variety French Fork Incised, var. McNust (Brown 1998:16; Phillips 1970:86). In the Lower Mississippi Valley, this type is believed to date from ca. A.D. 850-1000 (Brown 1998:55), in the middle part of the Coles Creek period, contemporaneous with the earliest, or Formative (i.e., Story 1990), Caddo period in East Texas.

Finally, about $31 \%$ of the incised sherds tabulated in Table 3 have only a single straight incised line.

The various incised-punctated rim and body sherds from the Grace Creek \#1 site account for only $7.6 \%$ of the decorated sherds in the Early Caddo component, including $4 \%$ of the rims (Table 4 ). There is a wide variety of decorative elements represented in these incised-punctated vessels, however, with several different types represented in this part of the Grace Creek \#1 decorated sherd assemblage.

The most distinctive of the incised-punctated sherds are the four Beldeau Incised, var. Beldeau rim and body sherds (Figure 6a-d). They have a cross-hatched incised zone around the rim, and punctations at the center of each diamond shape created by the cross-hatched incised lines. This is another ceramic type defined in the Lower Mississippi Valley (see Brown 1998:13; Phillips 1970:58), and a type characteristic of the ca. A.D. $850-1000$ period there. 
Table 3. Other Incised decorative elements.

\begin{tabular}{|c|c|c|c|}
\hline Decorative element & Rim & Body & $\mathrm{N}$ \\
\hline diagonal lines (Dunkin Incised) & 2 & - & 2 \\
\hline $\begin{array}{l}\text { diagonal opposed lines } \\
\text { (Dunkin Incised) }\end{array}$ & 3 & 7 & 10 \\
\hline opposed lines, broad line & - & 1 & 1 \\
\hline opposed lines, closely spaced & - & 1 & 1 \\
\hline opposed and parallel lines* & - & 1 & 1 \\
\hline opposed and parallel, broad line & - & 1 & 1 \\
\hline vertical lines & - & 1 & 1 \\
\hline widely spaced parallel lines & - & 19 & 19 \\
\hline widely spaced parallel lines* & - & 3 & 3 \\
\hline widely spaced broad parallel lines & - & 5 & 5 \\
\hline closely spaced parallel lines & - & 29 & 29 \\
\hline closely spaced parallel lines* & - & 1 & 1 \\
\hline closely spaced broad parallel lines & - & 2 & 2 \\
\hline very closely spaced parallel lines & - & 15 & 15 \\
\hline broad parallel lines & - & 1 & 1 \\
\hline broad parallel lines* & - & 1 & 1 \\
\hline parallel lines & - & 14 & 14 \\
\hline parallel lines* & - & 4 & 4 \\
\hline two parallel sets of lines & - & 1 & 1 \\
\hline single straight line & - & 31 & 31 \\
\hline single straight broad line & - & 1 & 1 \\
\hline \multicolumn{4}{|l|}{ widely spaced parallel to } \\
\hline curvilinear lines & - & 1 & 1 \\
\hline broad curvilinear lines & - & 2 & 2 \\
\hline widely spaced curvilinear lines & - & 1 & 1 \\
\hline $\begin{array}{l}\text { very closely spaced, curvilinear } \\
\text { zone (French Fork Incised) }\end{array}$ & - & 2 & 2 \\
\hline int. curvilinear lines & - & 1 & 1 \\
\hline Totals & 5 & 146 & 151 \\
\hline
\end{tabular}

Two other incised-punctated sherds have diagonal incised lines either below or above a single row of tool punctations (see Figure 6e-f), while another two (including a rim) have horizontal incised lincs with a row of crescent-shaped punctations bctween the lines. These sherds are from early Caddo utility ware Weches Fingernail Impressed, var. Weches vessels (Stokes and Woodring 1981). 


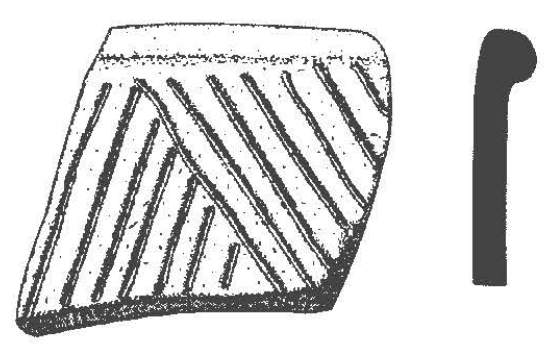

a
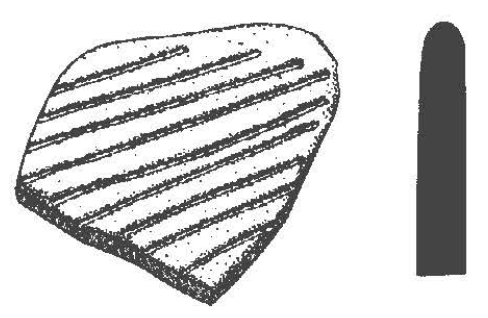

c

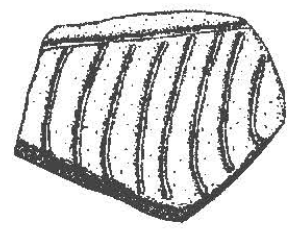

$\mathrm{e}$

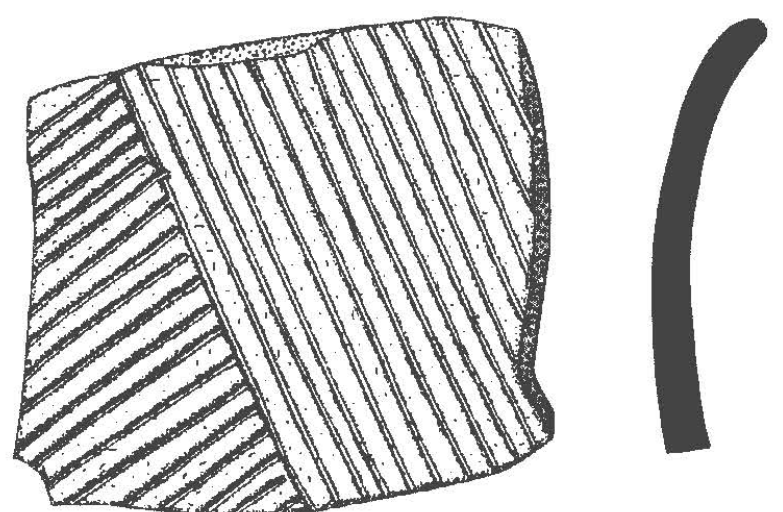

b

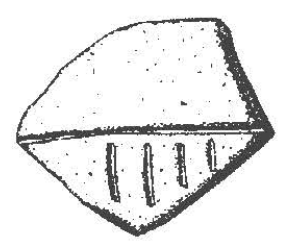

d

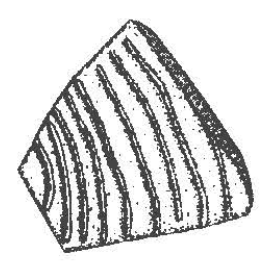

f

Figure 5. Other ineised decorative elements: a-b, Dunkin Incised; c, diagonal incised rim sherd, cf. Dunkin Incised; d, opposed incised lines; e-f, French Fork Incised body sherds.

The remainder of the incised-punctated sherds in this category of decorated sherds are from vessels that have incised panels (see Figure $6 \mathrm{~g}, \mathrm{i}, \mathrm{k}$ ) or zones (Figure $6 \mathrm{~h}-\mathrm{j}, \mathrm{i}-\mathrm{o}$ ) filled with tool punctations or cane punctations. In most cases, the incised zones are triangular-shaped and usually filled with tool punctations (Figure 6n-o), but cane punctations are also occasionally used as part of the decorative elements. These are sherds that are likely from Pennington Punctated Incised vessels, including carinated bowls. Sherds from vessels that have curvilinear incised zones (see Figure 6h, j, l-m) have the zones lilled with either cane or tool punctations; these are from Crockett Curvilinear lncised vessels.

The punctated sherds account for approximately $7 \%$ of the decorated sherds in the Early Caddo component at the Grace Creek \# 1 site, $5 \%$ of the rim sherds and $7.9 \%$ of the body sherds (see Table 1). The sample includes both fingernail (29\%) and tool punctated $(71 \%)$ examples, including those where the punctations are randomly or freely placed on the vessel body (Figure $7 \mathrm{a}, \mathrm{c}$ ), or are in rows (Figure 7b, d-e). One Weches Fingernail Impressed, var. Alto rim sherd (Figure 7d) has both crescent-shaped and triangular-shaped rows of punctations. 
Table 4. Incised-punctated sherd decorative elements.

\begin{tabular}{|c|c|c|c|}
\hline Dccorative element & $\operatorname{Rim}$ & Body & $\mathrm{N}$ \\
\hline \multicolumn{4}{|l|}{ Incised-Punctated } \\
\hline $\begin{array}{l}\text { cross-hatched incised lines with a single } \\
\text { punctate within each rectangle or diamond el. } \\
\text { (Beldeau Incised) }\end{array}$ & 1 & 3 & 4 \\
\hline $\begin{array}{l}\text { incised panels filled with small tool punctates } \\
\text { (cf. Pennington Punctated-Incised) }\end{array}$ & - & 3 & 3 \\
\hline $\begin{array}{l}\text { parallel incised lines adjacent to tool punctate- } \\
\text { filled zonc }\end{array}$ & - & 3 & 3 \\
\hline $\begin{array}{l}\text { curvilinear incised zone filled with cane punctates } \\
\text { (cf. Crockett Curvilinear Inciscd) }\end{array}$ & - & 2 & 2 \\
\hline triangular incised zone filled with tool punctates & - & 2 & 2 \\
\hline $\begin{array}{l}\text { horizontal incised lines with crescent-shaped } \\
\text { punctations between lines, cf. Weches }\end{array}$ & 1 & 1 & 2 \\
\hline \multicolumn{4}{|l|}{ Fingernail Impressed, var. Weches } \\
\hline $\begin{array}{l}\text { curvilincar inciscd zone filled with tool punctates } \\
\text { curvilinear incised zone filled with impressed }\end{array}$ & 1 & - & 1 \\
\hline $\begin{array}{l}\text { curvilinear incised zone filled with impressed } \\
\text { punctatc rows }\end{array}$ & - & 1 & 1 \\
\hline $\begin{array}{l}\text { closely-spaced parallel lines above a triangular } \\
\text { tool-punctated row }\end{array}$ & - & 1 & 1 \\
\hline $\begin{array}{l}\text { incised panel filled with cane punctates } \\
\text { (cf. Pennington Punctated Incised) }\end{array}$ & - & 1 & 1 \\
\hline \multicolumn{3}{|l|}{ cross-hatched lines and triangular tool-punctate } & 1 \\
\hline $\begin{array}{l}\text { parallel incised lincs adjacent to cane punctated } \\
\text { filled zone (cf. Pennington Punctated Incised) }\end{array}$ & - & 1 & 1 \\
\hline triangle incised zone filled with cane punctates & - & 1 & 1 \\
\hline diagonal-horizontal lines above tool punctated row & - & 1 & 1 \\
\hline tool punctated row at lip, diagonal lines on rim & 1 & - & 1 \\
\hline opposed incised lines and tool punctated zones & - & 1 & 1 \\
\hline \multicolumn{4}{|l|}{ Band Punctated } \\
\hline $\begin{array}{l}\text { parallel incised lines with rows of tool } \\
\text { punctations between sets of lines }\end{array}$ & - & 1 & 1 \\
\hline Totals & 4 & 23 & 27 \\
\hline
\end{tabular}

The most unique punctated sherd in the assemblage has threc rows of punctations on an exterior thickened rim, and the interior rim has at least two curvilinear incised lines (see Figure 7e-e'). This style of decorated rim has not been identified with a known East Texas ceramic type. 


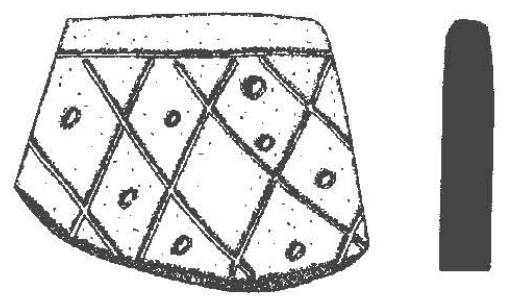

a
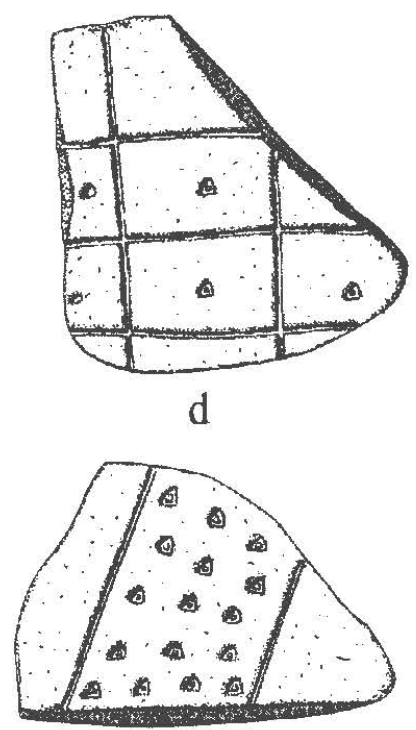

g

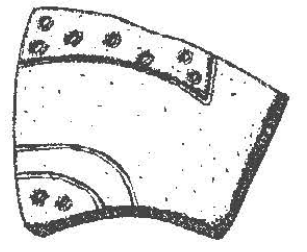

j

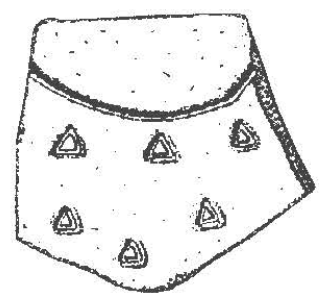

m

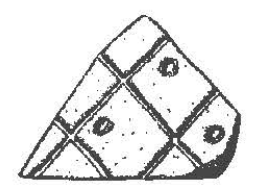

b

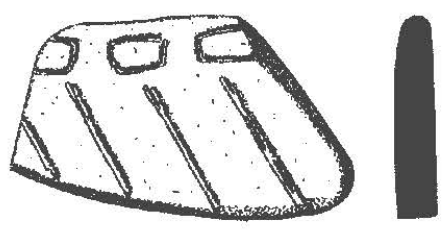

e

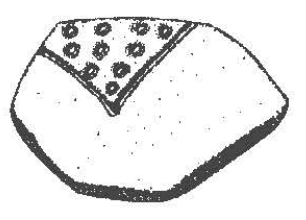

h

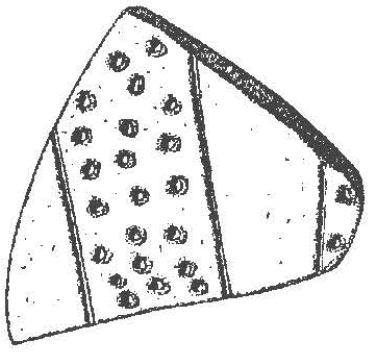

k

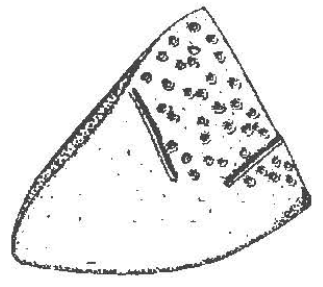

n

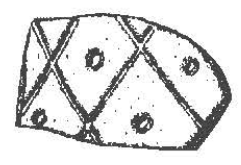

c

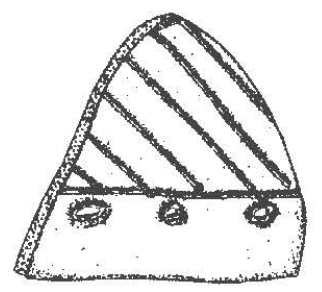

f

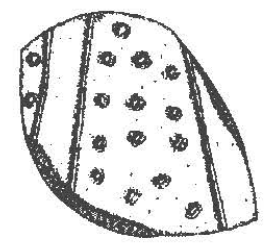

i

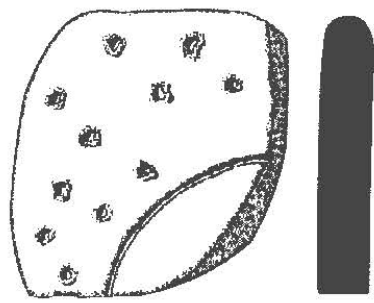

I

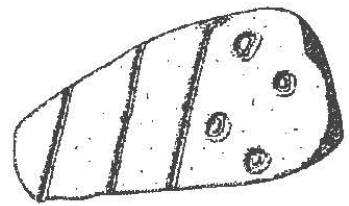

o

Figure 6. Incised-punctated sherds: a-d, Beldeau Incised, var. Beldeau rim and body sherds; e, tool punctated and diagonal incised; $\mathrm{f}$, tool punctated row and horizontal and diagonal incised lines; $\mathrm{g}, \mathrm{i}, \mathrm{k}$, incised pancls filled with tool or cane punctations, cf. Pennington Punctated Incised: h, j, curvilinear incised zones filled with cane punctations (cf. Crockett Curvilinear Incised); 1-m curvilinear incised zones filled with punctations; $n$, triangular incised zones filled with cane punctations; o, parallel incised lines adjacent to a tool punctated-filled zone. 
Table 5. Punctated decorative elements.

\begin{tabular}{|c|c|c|c|}
\hline Decorative element & Rim & Body & $\mathrm{N}$ \\
\hline fingernail punctated rows & - & 5 & 5 \\
\hline free fingernail punctated & - & 1 & 1 \\
\hline opposed fingernail punctated rows & 1 & - & - \\
\hline single fingernail punctate & - & 1 & 1 \\
\hline tool punctated rows & 3 & 6 & 9 \\
\hline frec tool punctated & - & 3 & 3 \\
\hline opposed linear tool punctates & - & 1 & 1 \\
\hline free linear tool punctates & - & 1 & 1 \\
\hline crescent to triangular tool punctates & 1 & - & 1 \\
\hline single tool punctate & - & 1 & 1 \\
\hline Totals & 5 & 19 & 24 \\
\hline
\end{tabular}

With two exceptions, the incised-impressed triangle sherds and the sherds with only impressed triangles are from Coles Creek Incised, var. Coles Creek vessels (Table 6). There are 26 such sherds in the Grace Creek \#1 site decorated sherd assemblage, including three rims (Figures 8a-d and 9a-b, d). These sherds have a single row of large impressed-punctated triangles, "evidently made with a corner of the same flat-ended tool" (Phillips 1970:70) used to make the horizontal incised lines on the vessels.

One of the two exceptions in this group of decorated sherds that are not var. Coles Creek is a rim sherd with multiple impressed triangles below multiple horizontal incised lines, which is not a distinguishing characteristic of Coles Creek Incised, var. Coles Creek (Phillips 1970:70), with its single row of punctations below the incised lines. The other is a rim sherd with rows of angular impressions, likely from a Weches Fingernail Impressed, var. Alto rim sherd (see Table 6).

The most distinctive of the horizontal incised sherds from the Grace Creek \#1 site are those that have rows of large impressed triangles between the incised lines (Figure 10b-e), as well as a single row of impressed triangles below the bottom incised line, with sometimes as many as three to four rows of small and large impressed triangles between the same number of horizontal lines (Figure 10d-e). Two other sherds have rows of small crescent-shaped punctations, and are classified as Weches Fingernail Impressed, var. Weches (Figure 10f-g). Girard (2009a:28) has made the suggestion that these sherds with impressed punctations between incised lines are a regional variant of Coles Creek Incised, var. Coles Creek. Wcbb and McKinney (1975:73 and Figure 8e) include sherds such as these within Coles Creek Incised, var. Coles Creek.

The ridged-pinched and incised-ridged-pinched rim and body sherds $(n=10)$ are from Hollyknowe Ridge Pinched vessels (see Phillips 1970:89), probably var. Hollyknowe (Brown 1998:28) or a locally produced example of the type. They comprise $2.9 \%$ of the decorated sherds in the early Caddo component (see Table 1) at the Grace Creek \#I site. These sherds have vertical, diagonal, and straight-parallel pinched ridges covering the rim and body. Two body sherds have parallel pinched ridges adjacent to parallel incised lines. 


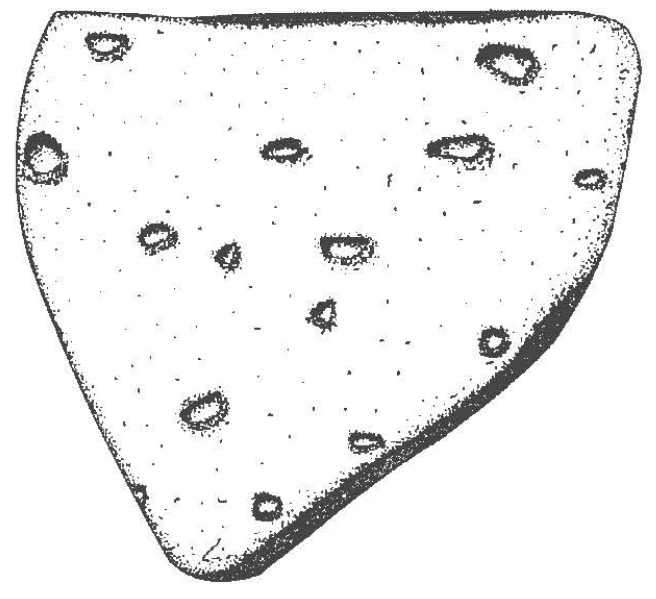

a

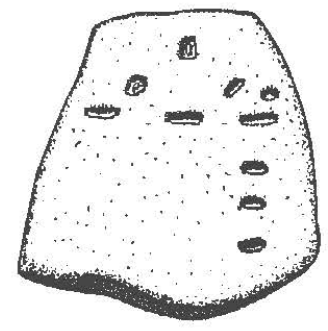

C

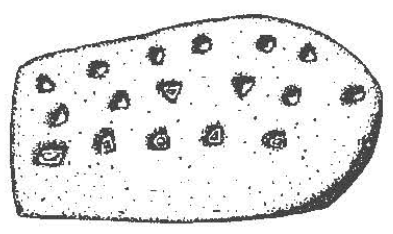

$\mathrm{e}$

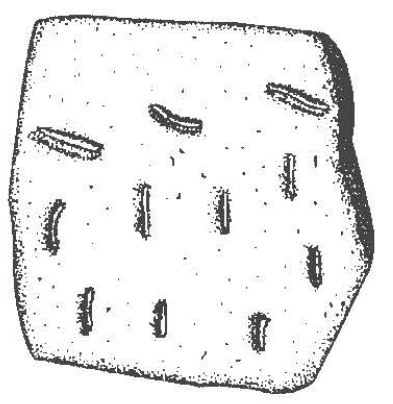

b

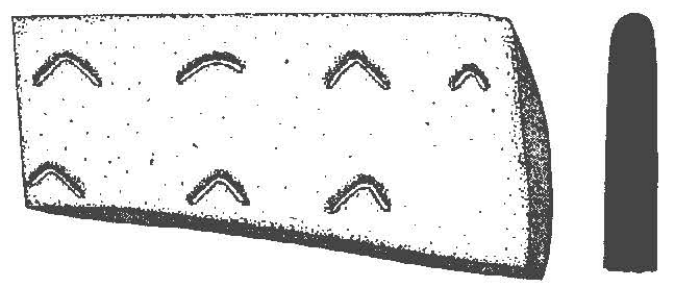

d
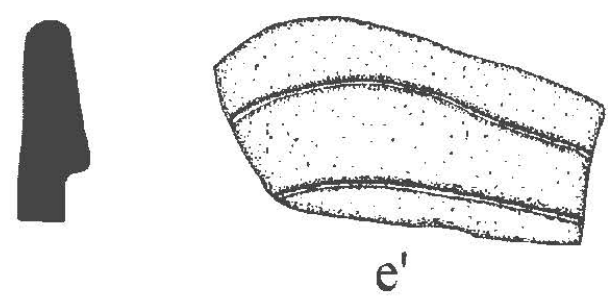

Figure 7. Punctated sherds: a, free tool punctations; b, opposed fingernail punctated rows; c, tool punctations; d, crescentshaped to triangular punctations, cf. Weches Fingernail Impressed, var. Alto; e-e', tool punctated on exterior rim, and curvilinear incised lines on sherd interior.

Two rim sherds ( $0.6 \%$ of the decorated sherds in the early Caddo component) have lip notches as the only form of decoration ( $\mathrm{sec}$ Table 1). The lirst of these has diagonal lip notches on a direct rim with a flat lip; the rim has a roughened exterior, and is thickened on the interior vessel surface. The second rim has notches along the exterior edge of a rim where the lip has been folded flat, almost to a 90 degree angle, comparable to the Redwine mode of lip treatment also seen in East Texas Caddo sites (Walters 2010), albeit mainly on sites dating after ca. A.D. 1200, not in early Caddo contexts.

The one band punctated (cf. Webb 1963:Figure 9r-s, u; Jeffrey S. Girard, April 2010 personal communication) sherd ( $0.3 \%$ of the decorated sherds in the early Caddo component) from the Grace Creck \#1 site has multiple parallel incised lines with single rows of tool punctations betwcen sets of incised lines (see Figure 10a). I have separated this kind of decorative element from those previously discussed that have large impressed triangles between sets of incised lines (see Figures 9c-e and 10b-e), primarily 


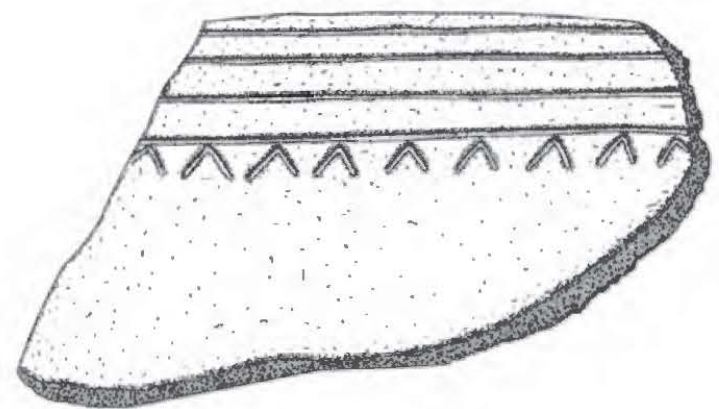

a

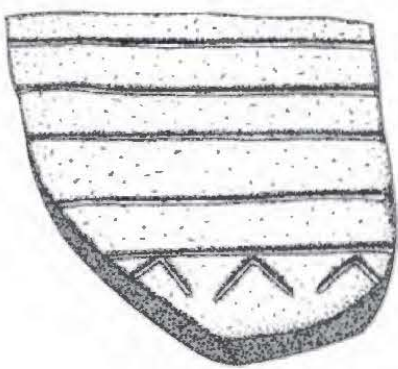

b
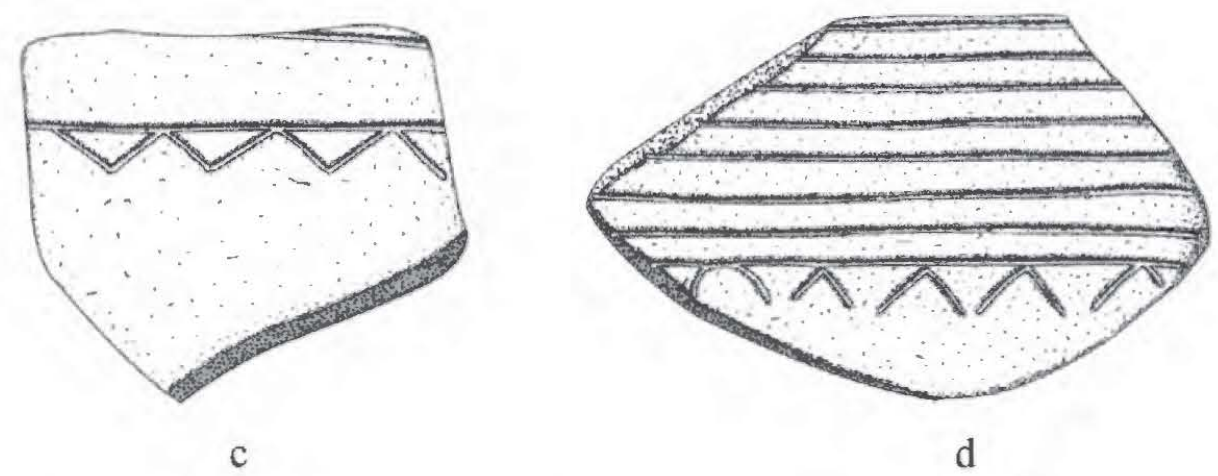

Figure 8. Coles Creek Incised, var. Coles Creek sherds: a-d, horizontal lines and a row of impressed triangles at the base of the decoration on the rim.

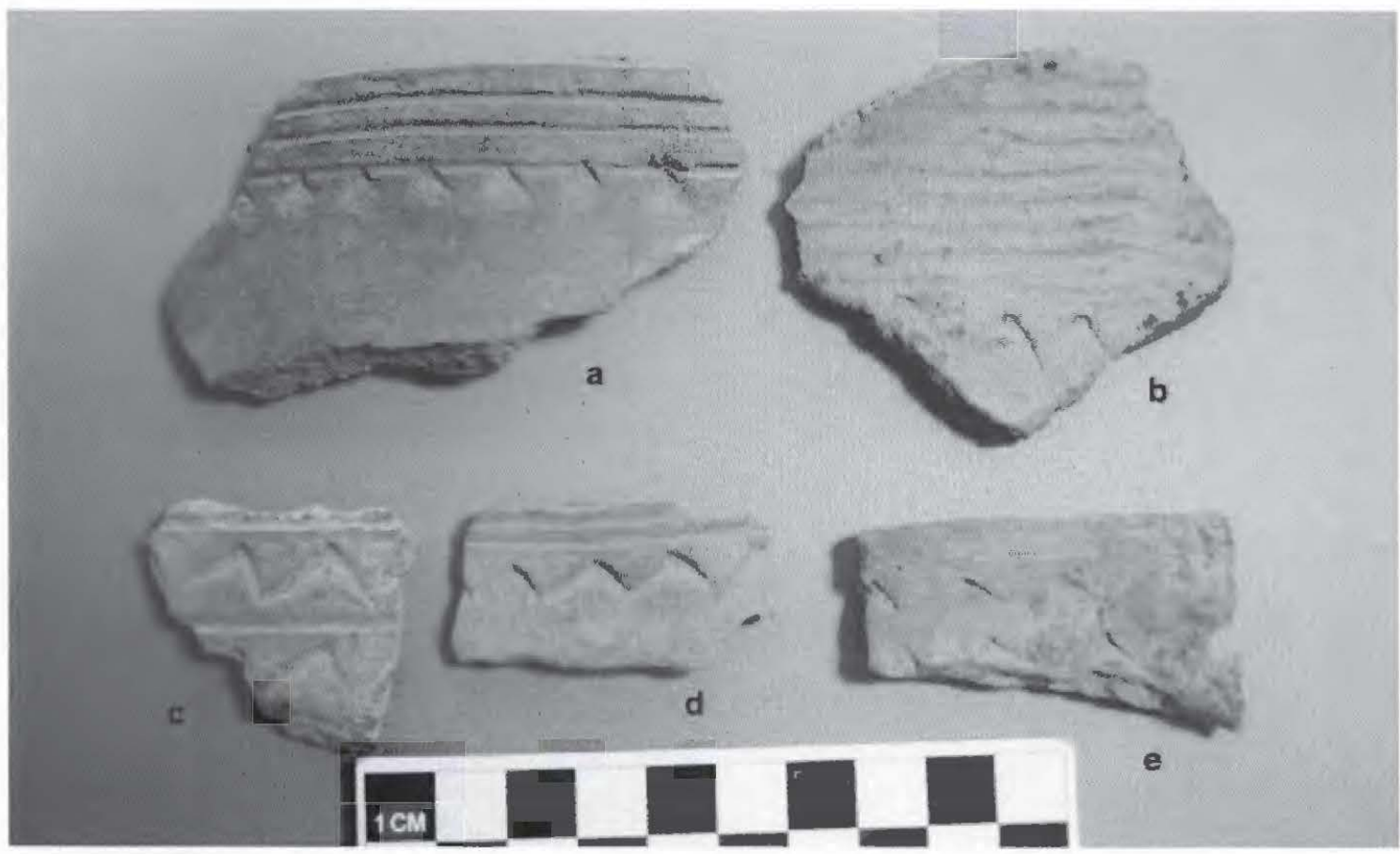

Figure 9. Coles Creek Incised, var. Coles Creek, and other incised-impressed sherds: a-b, d, Coles Creck Incised, var. Coles Creek; c, horizontal incised lines with impressed triangles between the incised lines; e, impressed triangles. 
Table 6. Incised-Impressed and Impressed sherds from the Grace Creek \#1 site.

\begin{tabular}{|c|c|c|c|}
\hline Decorative element & Rim & Body & $\mathrm{N}$ \\
\hline \multicolumn{4}{|l|}{ Incised lines-impressed triangles } \\
\hline $\begin{array}{l}\text { horizontal lines above row of impressed } \\
\text { triangles }\end{array}$ & - & 9 & 9 \\
\hline $\begin{array}{l}\text { horizontal incised lines with impressed } \\
\text { triangles between lines } \\
\text { closely-spaced and broad horizontal lines }\end{array}$ & 2 & 4 & 6 \\
\hline $\begin{array}{l}\text { above row of impressed triangles } \\
\text { closely-spaced horizontal lines above }\end{array}$ & - & 4 & 4 \\
\hline $\begin{array}{l}\text { row of small impressed triangles } \\
\text { multiple horizontal incised lines above }\end{array}$ & - & 1 & 1 \\
\hline $2+$ rows of impressed triangles & 1 & - & 1 \\
\hline \multicolumn{4}{|l|}{$\underline{\text { Impressed elements }}$} \\
\hline horizontal row of impressed triangles & - & 5 & 5 \\
\hline single impressed triangle & - & 1 & 1 \\
\hline $\begin{array}{l}\text { rows of angular impressions, cf. Weches } \\
\text { Fingernail Impressed, var. Alto }\end{array}$ & 1 & - & 1 \\
\hline Totals & 4 & 24 & 28 \\
\hline
\end{tabular}

because the large impressed triangles suggest a direct connection with the Coles Creek Incised or Weches Fingernail Impressed types, although one that has not been recognized as a distinct variety of the type.

The engraved fine wares comprise only a small part of the decorated ceramic vessel sherds from the site $(6.4 \%$ of all the sherds; $10 \%$ of the rims), as previously mentioned. They include sherds from carinated bowls and bottles, and sherds from readily identifiable Hickory Engraved and Holly Fine Engraved vessels are present in the collection (Table 7).

The Hickory Engraved sherds have one to several (and then equally-spaced) horizontal engraved lines encircling the rim of carinated bowls, beginning either under the lip or as a single line placed midway down the rim (Figure 1le, g). The one Holly Fine Engraved sherd in the fine wares has opposed sets of closely spaced engraved lines divided by an excised triangular element (Figure 11f, see Suhm and Jelks 1962:Plate 39a).

Other engraved carinated bowl sherds have diagonal lines on the rim panel, cross-hatched lines (see Figure 1Ia), or one with a single horizontal engraved line adjacent to a horizontal hatched panel (see Figure 11d). Another carinated bowl rim has part of a curvilinear or oval-shaped decorative element. None of these sherds are identifiable to a defined East Texas Caddo ceramic type. but they do indicate that the engraved sherds at the Grace Creek \#1 site are diverse in their decorative styles.

Bottle sherds in the Grace Creek \#I decorated sherd assemblage have widely-spaced curvilinear engraved lines (see Figure $11 \mathrm{~b}-\mathrm{c}$ ) on vessel bodies. These may be from either Holly Fine Engraved or Spiro 


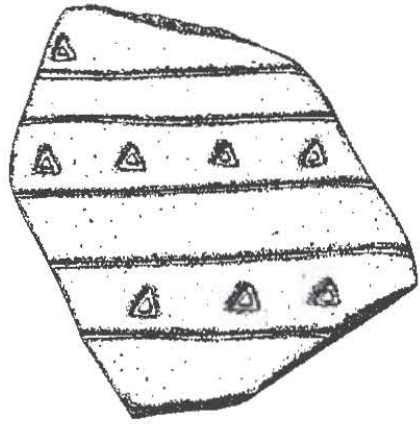

a
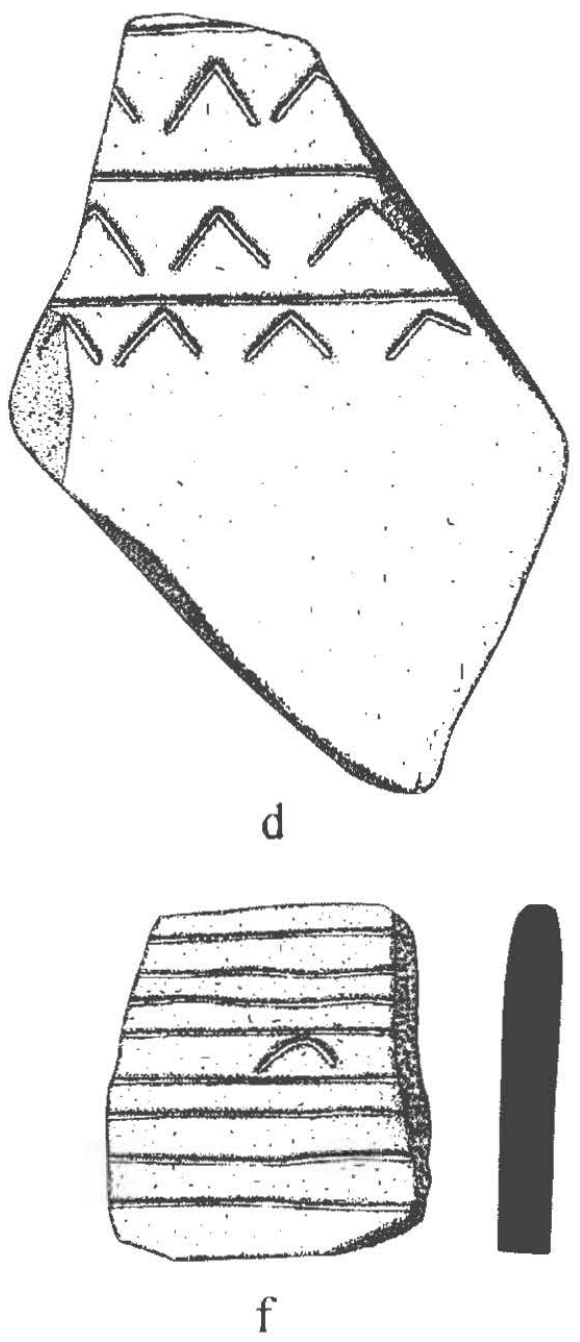

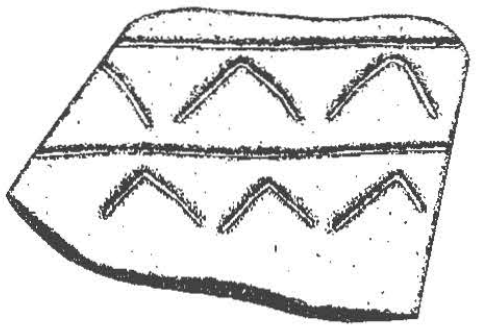

b

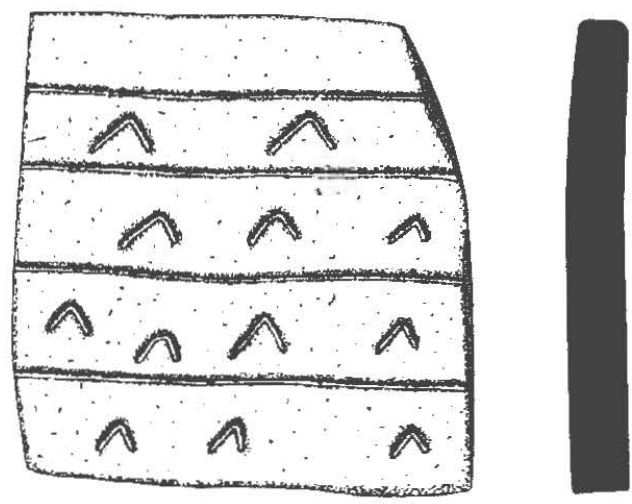

e

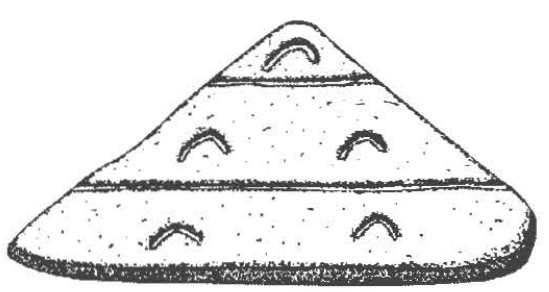

$\mathrm{g}$

Figure 10. Incised-impressed and band punctated sherds: a, band punctated; b-e, horizontal incised with impressed triangles between the incised lines; $\mathrm{f}$-g, cf. Weches Fingernail Impressed, var. Werhes rim sherd. 
Table 7. Engraved decorative elements.

\begin{tabular}{|c|c|c|c|}
\hline Decorative element & Rim & Body & $\mathrm{N}$ \\
\hline $\begin{array}{l}\text { Holly Fine Engraved el., opposed } \\
\text { zones of finc lines and excised triangle }\end{array}$ & - & 1 & 1 \\
\hline cross-hatched lines & 1 & - & 1 \\
\hline diagonal lines & 1 & 1 & 2 \\
\hline $\begin{array}{l}\text { horizontal lines under the lip, cf. } \\
\text { Hickory Engraved }\end{array}$ & 2 & - & 2 \\
\hline $\begin{array}{l}\text { horizontal lines, widely-spaced, } \\
\text { Hickory Engraved }\end{array}$ & 2 & - & 2 \\
\hline $\begin{array}{l}\text { horizontal lines, closely-spaced, } \\
\text { Hickory Engraved }\end{array}$ & 2 & - & 2 \\
\hline horizontal lines on pancl & - & 1 & 1 \\
\hline singlc horizontal line & 1 & - & 1 \\
\hline $\begin{array}{l}\text { horizontal line and horizontal hatched } \\
\text { zonc }\end{array}$ & & & \\
\hline $\begin{array}{l}\text { zonc } \\
\text { parallel lines }\end{array}$ & $\begin{array}{l}- \\
-\end{array}$ & $\begin{array}{l}1 \\
1\end{array}$ & $\begin{array}{l}1 \\
1\end{array}$ \\
\hline widely spaced parallel lines & - & 2 & 2 \\
\hline single straight line & - & 2 & 2 \\
\hline straight and curvilinear line & - & 1 & 1 \\
\hline curvilinear line & 1 & - & 1 \\
\hline curvilinear lines, widely spaced & - & 2 & 2 \\
\hline Totals & 10 & 12 & 22 \\
\hline
\end{tabular}

Engraved vessels. Other bottle shords are from Hickory Engraved vessels, as they have simple horizontal lines on cither the bottle rim or the upper part of the vessel body (see Figure $1 \mathrm{lh}$ ).

Turning from the discussion of the decorated sherd asscmblage, the Early Caddo ceramics from the Grace Creek \#1 site are from vessels that are predominantly tempered with grog or crushed sherds (Table 8). This includes both the utility wares and the fine wares. Crushed and burned bone is a secondary temper, as it was present in $23.4 \%$ of the utility ware sherds and $35.7 \%$ of the fine wares.

Crushed hematite pebbles were added to the paste on about $5 \%$ of the sherds (see Table 8 ). Another $5.2 \%$ of the sherds arc from vessels that were not fired at a sufficiently high temperature or for a sufficiently long duration to combust the organic materials in the paste. Finally, $2.9 \%$ of the sherds analyzed in detail-all utility wares-have a sandy paste, indicating that a naturally sandy clay was selected for the manufacture of a few utility ware vessels.

Most of the sherds from the Early Caddo component at the Grace Creek \#I site are from vessels that were fired in a reducing or low oxygen environment, perhaps smothered in coals or other fucls. The percentage of sherds from reduced-fired vessels is $93.6 \%$ in the analyzed utility wares and $92.3 \%$ in the fine wares (Table 9). Of these, the majority are from vessels that were then cooled in the open air (57\%), leaving a thin oxidized lens in the core on either one or both vessel surlaces, and one or both vessel surfaces themselves a yellowish to reddish-brown color. This form of firing was particularly favored among the fine wares $(84.6 \%)$. Reduced-fired and cooled vessel sherds are also common in the utility wares (55.2\%) (Table 9). 


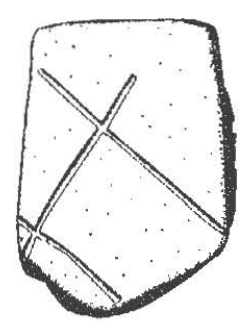

a

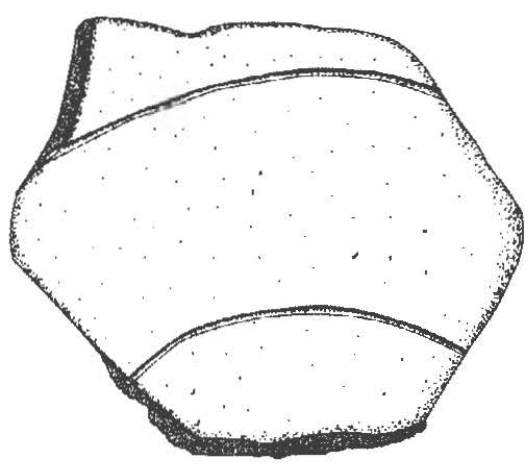

c

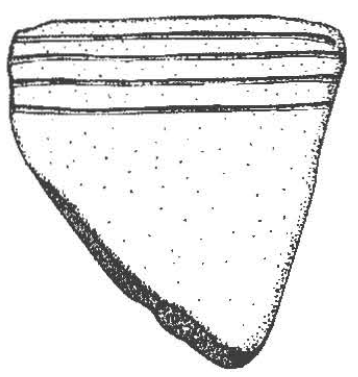

e

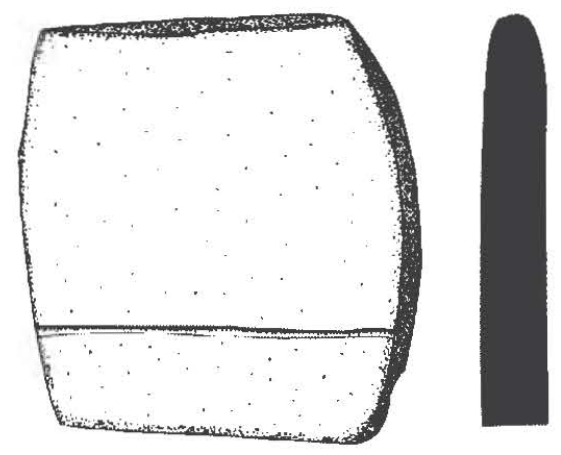

g

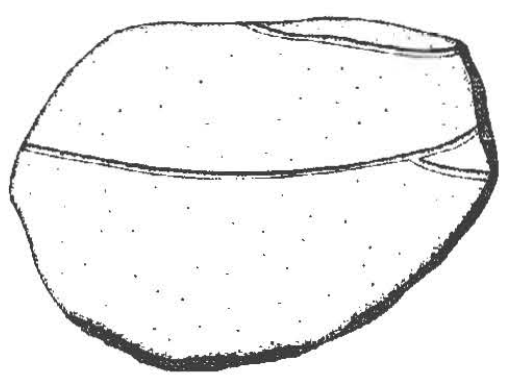

b

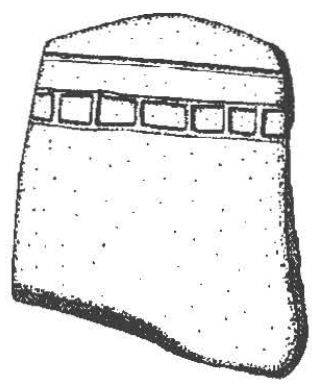

d

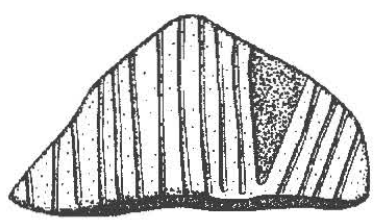

f

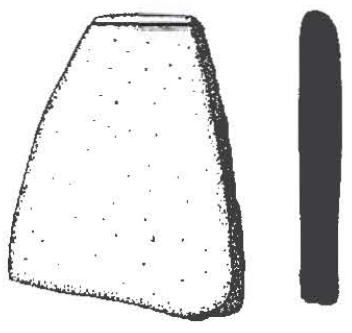

h

Figure 11. Engraved rim and body sherds: a. cross-hatched; b-c, curvilinear lines; d, parallel and hatched lines; e, Hickory Engraved: f, Holly Fine Engraved; g-h, horizontal engraved rim sherds, cf. Hickory Engraved. 
Table 8. Temper use in the Grace Creek \#1 Site Early Caddo decorated wares.*

\begin{tabular}{|c|c|c|c|c|c|}
\hline \multirow[t]{2}{*}{ Temper class } & \multicolumn{2}{|c|}{ Utility wares } & \multicolumn{2}{|c|}{ Finc wares } & \multirow[t]{2}{*}{$\mathrm{N}$} \\
\hline & No. & $\%$ & No. & $\%$ & \\
\hline grog & 113 & 71.5 & 8 & 57.1 & 121 \\
\hline grog-organics & 2 & 1.3 & - & - & 2 \\
\hline grog-sandy paste & 4 & 2.5 & - & - & 4 \\
\hline grog-bonc & 16 & 10.1 & 3 & 21.4 & 19 \\
\hline grog-bone-organics & 2 & 1.3 & - & - & 2 \\
\hline grog-hematitc & 2 & 1.3 & 1 & 7.1 & 3 \\
\hline grog-bone-hematite & 3 & 1.9 & - & - & 3 \\
\hline bone & 9 & 5.7 & - & - & 9 \\
\hline bone-hematite & 3 & 1.9 & - & - & 3 \\
\hline bone-organics & 3 & 1.9 & 2 & 14.3 & 5 \\
\hline bonc-sandy paste & 1 & 0.6 & - & - & 1 \\
\hline $\begin{array}{l}\text { Summary of sherd temper data: } \\
\text { sherds with grog temper }\end{array}$ & 142 & 89.9 & 12 & 85.7 & 154 \\
\hline sherds with bone temper & 37 & 23.4 & 5 & 35.7 & 42 \\
\hline sherds with hematite temper & 8 & 5.1 & 1 & 7.1 & 9 \\
\hline sherds with organics & 7 & 4.4 & 2 & 14.3 & 9 \\
\hline sherds with sandy paste & 5 & 3.2 & - & - & 5 \\
\hline Totals & 158 & 100.0 & 14 & 100.0 & 172 \\
\hline
\end{tabular}

Oxidized and incompletely oxidized vessel sherds only comprise $5.9 \%$ of the sherd sample analyzed in detail, and it is clear that firing and cooling in the open air was not a preferred firing method by the early Caddo potters; the examples of these sorts of firings are confined almost exclusively to the utility wares (see Table 9). Overall, the vessel firings were well done and well-controlled.

\section{Late Caddo decorated sherds}

The Late Caddo decorated sherds that were identilied at the Grace Creek \#1 site are dominated by utility ware rim and body sherds $(97.5 \%)$. These include brushed sherds $(82.3 \%$, Figure $12 \mathrm{~h})$ likely from Bullard Brushed jars or the brushed bodies from sherds decorated in several different ways on the rim, brushed-incised $(6.3 \%)$, brushed-appliqued (3.8\%, Figure 12e-f), brushed-appliquedpunctated (1.3\%, Figure 12d), brushed-incised-punctated $(1.3 \%)$, and brushed-punctated sherds $(1.3 \%$, Figure $12 \mathrm{~g})$, as well as one rim with a row of linear punctates below the lip (1.3\%, Figure 12c). The brushed-incised, brushed-appliqued, brushed-appliqued-punctated, and brushed-incisedpunctated sherds are probably from Pease Brushed-Incised vessels, where the body of the vessel is divided into panels by appliqued fillets, punctations, or incised lines, and the panels themselves filled with vertical brushing marks. Both Bullard Brushed and Pease Brushed-Incised vessels are common Titus phase vessel types. 
Table 9. Firing conditions in the Grace Creek \#1 site Early Caddo decorated sherds.

\begin{tabular}{|c|c|c|c|c|c|}
\hline \multirow[t]{2}{*}{ Firing conditions } & \multicolumn{2}{|c|}{ Utility wares } & \multicolumn{2}{|c|}{ Fine wares } & \multirow[t]{2}{*}{$\mathrm{N}$} \\
\hline & No. & $\%$ & No. & $\%$ & \\
\hline A (oxidizing) & 6 & 3.8 & - & - & 6 \\
\hline B (reducing) & 60 & 38.5 & 1 & 7.7 & 61 \\
\hline $\mathrm{C}$ & - & 1 & 1 & 7.7 & 1 \\
\hline D (incompletely & 1 & 0.6 & - & - & 1 \\
\hline E oxidized) & 2 & 1.3 & - & - & 2 \\
\hline $\mathrm{F}$ & 23 & 14.8 & 2 & 15.4 & 25 \\
\hline $\mathrm{G}$ (fired in a reducing & 51 & 32.7 & 7 & 53.8 & 58 \\
\hline $\begin{array}{l}\text { H environment and } \\
\text { cooled in the open } \\
\text { air) }\end{array}$ & 12 & 7.7 & 2 & 15.4 & 14 \\
\hline $\mathrm{J}$ & - & - & - & - & 0 \\
\hline K (sooted, smudged, & - & - & - & - & 0 \\
\hline $\mathrm{L}$ refired) & 1 & 0.6 & - & - & 1 \\
\hline Summary of firing conditions & & & & & \\
\hline$\%$ oxidizing & 6 & 3.8 & - & - & 6 \\
\hline$\%$ incompletely oxidized & 3 & 1.9 & 1 & 7.7 & 4 \\
\hline$\%$ reducing & 60 & 38.5 & 1 & 7.7 & 61 \\
\hline $\begin{array}{l}\% \text { fired in a reducing } \\
\text { environment, cooled in } \\
\text { an oxidizing environment }\end{array}$ & 86 & 55.1 & 11 & 84.6 & 97 \\
\hline $\begin{array}{l}\% \text { irregular or poorly controlled } \\
\text { firing }\end{array}$ & 1 & 0.6 & - & - & 1 \\
\hline Totals & 156 & 100.0 & 13 & 100.0 & 169 \\
\hline
\end{tabular}

The two Late Caddo fine ware sherds from the Grace Creek \#1 site are from two different Ripley Engraved carinated bowls. The first has a scroll element with its central element a swastika in circle (see Figure 12a, Ripley Engraved, var. Galt, following Perttula et al. [2010]), with the second, Ripley Engraved, var. McKinney, having a diamond element in a pendant triangle motif (Figure 12b). These decorative elements are most common in post-A.D. 1500 Titus phase sites, with the use of the var. McKinney motif thought to date to ca. A.D. 1600 and after (Perttula 1992:Table A-2).

Although the use of grog temper is preferred as the principal aplastic added to the paste of the Late Caddo vessel sherds (Table 11), there is a significant secondary use of burned bone $(54.6 \%)$ and crushed hematite pieces $(15.2 \%)$; these temper uses are two-three times higher in the Late Caddo ceramics when 
Table 10. Decorative elements in the Late Caddo sherds from the Grace Creek \#1 site.

\begin{tabular}{|c|c|c|c|}
\hline Ware & Rim & Body & $\mathrm{N}$ \\
\hline \multicolumn{4}{|l|}{ Utility ware } \\
\hline horizontal brushed & 1 & - & 1 \\
\hline diagonal brushed & 1 & - & 1 \\
\hline vertical brushed & - & 2 & 2 \\
\hline $\begin{array}{l}\text { horizontal-diagonal } \\
\text { brushed }\end{array}$ & 1 & - & 1 \\
\hline parallel brushed & - & 54 & 54 \\
\hline overlapping brushed & - & 3 & 3 \\
\hline opposed brushed & - & 3 & 3 \\
\hline \multicolumn{4}{|l|}{ parallel brushed-straight } \\
\hline opposed brushed-straight & & & \\
\hline appliqued fillet & - & 1 & 1 \\
\hline $\begin{array}{l}\text { parallel brushed-straight } \\
\text { appliqued fillet, and } \\
\text { tool punctated row } \\
\text { through the brushing }\end{array}$ & - & 1 & 1 \\
\hline parallcl brushed-incised & - & 5 & 5 \\
\hline \multicolumn{4}{|l|}{ diagonal brushed-incised } \\
\hline and tool punctated row & - & 1 & 1 \\
\hline opposed brushed & - & 3 & 3 \\
\hline \multicolumn{4}{|l|}{ parallel brushed-straight } \\
\hline \multicolumn{4}{|l|}{ opposed brushed-straight } \\
\hline appliqued fillet & - & 1 & 1 \\
\hline $\begin{array}{l}\text { parallel brushed-straight } \\
\text { appliqued fillet, and } \\
\text { tool punctated row } \\
\text { through the brushing }\end{array}$ & - & 1 & 1 \\
\hline parallel brushed-incised & - & 5 & 5 \\
\hline \multicolumn{4}{|l|}{ diagonal brushed-incised } \\
\hline and tool punctated row & - & 1 & 1 \\
\hline \multicolumn{4}{|l|}{ parallel brushed-tool } \\
\hline punctated row & - & 1 & 1 \\
\hline $\begin{array}{l}\text { linear punctated row } \\
\text { under the lip }\end{array}$ & 1 & - & 1 \\
\hline
\end{tabular}


Table 10. Decorative elements in the Late Caddo sherds from the Grace Creek \#1 site, cont.

\begin{tabular}{llll}
\hline Ware & Rim & Body & N \\
\hline $\begin{array}{l}\text { Fine ware } \\
\text { scroll, swastika in } \\
\text { circle (Ripley Engraved, } \\
\text { var. Galt) }\end{array}$ & 1 & - & 1 \\
$\begin{array}{l}\text { diamond element } \\
\text { (Riplcy Engraved, var. } \\
\text { McKinney) }\end{array}$ & - & 1 & 1 \\
\hline Totals & 5 & 74 & 79 \\
\hline
\end{tabular}

compared to only $24.4 \%$ bone temper in the Early Caddo sherds and $5.2 \%$ hematite temper (see Table 8 ). The sample of analyzed sherds is small, but bone and hematite temper use is higher among the fine wares than is the case among the utility ware sherds. No naturally sandy clay was apparently used for vessel manufacture.

Ceramic sherds in the Grace Creek \# 1 Late Caddo component were from vessels fired by Caddo potters in diverse ways. The most common method was to fire the vessel in a reducing environment, but then cool it in the open air, leaving one or more oxidized surfaces $(48.5 \%)$, and well represented in both the utility wares and fine wares (Table 12). Reduced-fired vessels comprise $24.2 \%$ of the sherds analyzed in detail, compared to the other $27.3 \%$ of the sherds that were from vessels either incompletely oxidized or fired and cooled in an oxidizing environment (Table 12).

\section{Plain Sherds}

The 1403 plain sherds at the Grace Creek \#1 site include 89 rims, 1300 body sherds, and 14 base sherds. These are from carinated bowls, bowls, jars, and bottles. Orifice diameters range from $4.0-5.0 \mathrm{~cm}$ for bottle necks, and 10-30.0 cm for carinated bowls, jars, and bowls (Table 13). There are two distinct peaks in orifice diameter, the first between $13.0-16.0 \mathrm{~cm}$ (36.8\% of the measurable rims) and the second between $18.0-20.0 \mathrm{~cm}(34.7 \%)$. Overall, these are medium-sized plain vessels that account for the majority of the plain ware vessels used and discarded at the site, vessels that were probably meant to be used by individuals and families rather than for communal use.

The plain rim sherds have various rim and lip profiles (Table 14). The majority of the rim sherds come from vessels that have direct or vertical walls and a rounded lip, including jars, bowls, and carinated bowls. A few jars have everted rims, and $10.3 \%$ of the rims are from bowls with inverted profiles.

A few of the plain rim $(n=2)$ and body sherds $(n=1)$ have drill holes in them, possibly for use in suspending the vessel, or in the case of the body sherd, for use as a spindle whorls in weaving activities. The drill holes range from 7.2-10.6 mm in exterior diameter.

The Grace Creek \#1 site plain ware ceramics are tempered predominantly with grog or crushed pieces of fired clay $(92.1 \%)$, along with significant use of crushed and burned bone $(32.1 \%$, either as the sole temper or mixed with grog and/or hematite) or crushed hematite pieces $(21.3 \%$, in combination with grog and/or bone temper) as secondary temper inclusions (Table 15). The vessels from which these 


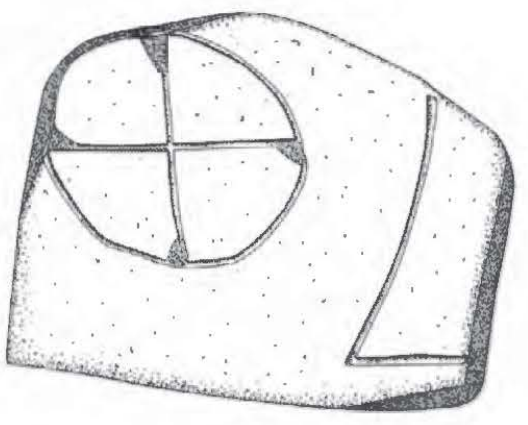

a

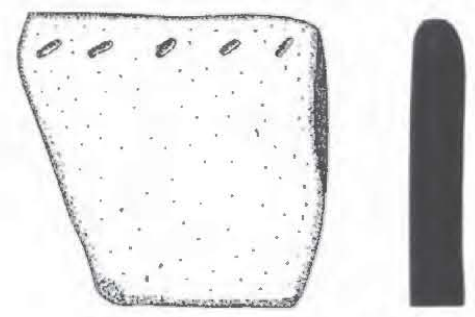

c

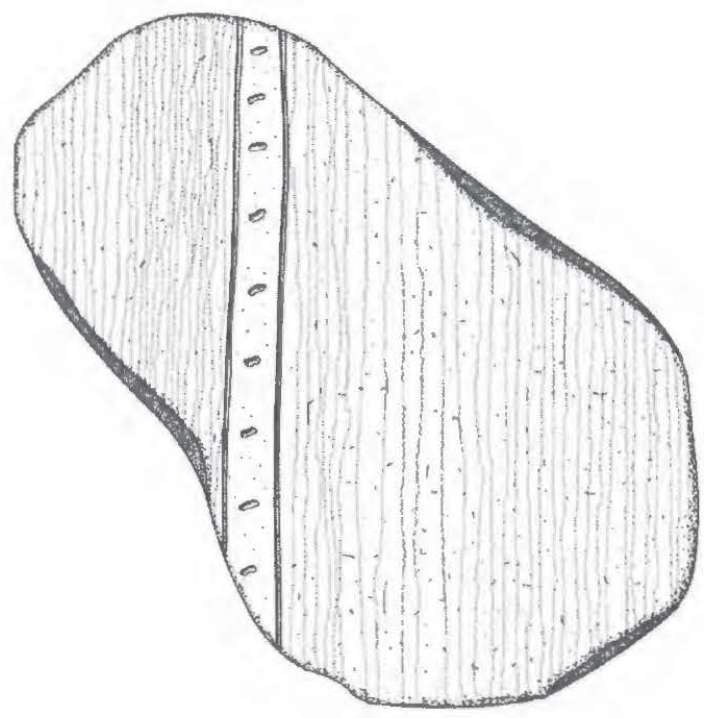

e

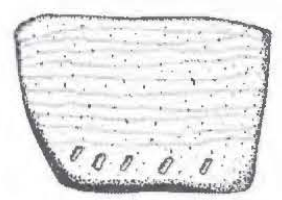

g

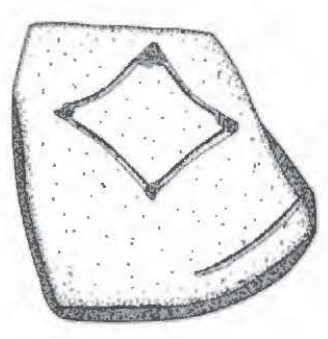

b

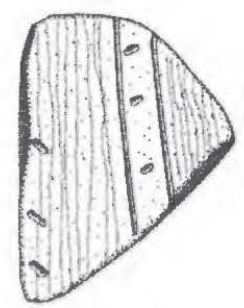

d

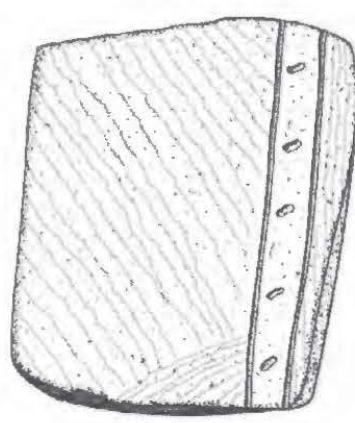

f

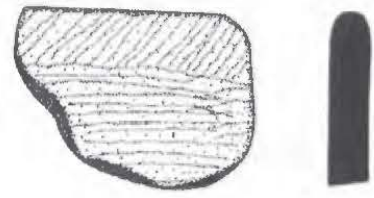

h

Figure 12. Late Caddo decorated sherds: a, Ripley Engraved, var. Galt sherd; b, Ripley Engraved, var. McKinney sherd; $\mathrm{c}$, linear tool punctated; d, brushed-appliqued and tool punctated; e-f, brushed and appliqued fillets; g, brushed and tool punctated; h, diagonal and horizontal brushed rim. 
Table 11. Temper use in the Grace Creek \#1 Site Late Caddo decorated wares.*

\begin{tabular}{|c|c|c|c|c|c|}
\hline \multirow[t]{2}{*}{ Temper class } & \multicolumn{2}{|c|}{ Utility wares } & \multicolumn{2}{|c|}{ Fine wares } & \multirow[t]{2}{*}{$\mathrm{N}$} \\
\hline & No. & $\%$ & No. & $\%$ & \\
\hline grog & 13 & 41.9 & - & - & 13 \\
\hline grog-organics & 1 & 3.2 & - & - & 1 \\
\hline grog-bone & 7 & 22.6 & 1 & 50.0 & 8 \\
\hline grog-hematite & 1 & 3.2 & - & - & 1 \\
\hline grog-bone-hematite & 1 & 3.2 & - & - & 1 \\
\hline bone & 5 & 16.1 & - & - & 5 \\
\hline bone-hematite & 2 & 6.4 & 1 & 50.0 & 3 \\
\hline bone-organics & 1 & 3.2 & - & - & 1 \\
\hline $\begin{array}{l}\text { Summary of sherd temper data: } \\
\text { shcrds with grog temper }\end{array}$ & 23 & 74.2 & 1 & 50.0 & 24 \\
\hline sherds with bone temper & 16 & 51.6 & 2 & 100.0 & 18 \\
\hline sherds with hematite temper & 4 & 12.9 & 1 & 50.0 & 5 \\
\hline Totals & 31 & 100.0 & 2 & 100.0 & 33 \\
\hline
\end{tabular}

sherds came must have been lired at a high enough temperature and for a sufficient length of time that the organic materials in the paste were successfully combusted.

Only $1.7 \%$ of the Grace Creek \# I site vessel sherds have a sandy paste (see Table 15). This suggests that a naturally sandy clay was not sought out by local Caddo potters for the manufacture of plain wares, although such alluvial clays were employed from time to time in vessel manufacture.

The plain ware sherds are from ceramic vessels fired almost exclusivcly in a reducing or low oxygen environment, probably smothered in the coals (Table 16). The percentage of sherds analyzed in detail indicate that $89.8 \%$ of the sherds are from vessels fired in a reducing environment.

As is the case with many other Caddo ceramic assemblages in East Texas, the majority of the vessels were actually fired in a reducing environment, but then cooled in a high oxygen environment (see Table 16). This led to the oxidation of a thin band at the vessel surface of either one ( $26.5 \%$, firing conditions $G$ and $\mathrm{H}$ ) or both (28.6\%, firing condition $\mathrm{F}$ ) surfaces (see Table 4), leaving a dark gray to black core and a lighter brown to yellowish-brown vessel surface.

\section{Other Ceramic and Clay Artifacts}

This group of clay artifacts first include two pieces of daub, suggesting that there may have been a clay and thatch-covered Caddo house on the Grace Creek \#1 site that had burned down. The provenience of the daub within the site is unknown. The second group is a clay object (grog-tempered) of unidentified function. It is a flattened, oval-shaped, fired clay object with rounded edges; it is haphazardly smoothed on both sides of the piece as well as the edges. This may be part of an effigy that was appended to a ceramic vessel or the body of an unfinished clay figurine. 
Table 12. Firing conditions in the Grace Creek \#1 site Late Caddo decorated sherds.

\begin{tabular}{|c|c|c|c|c|c|}
\hline \multirow[t]{2}{*}{ Firing conditions } & \multicolumn{2}{|c|}{ Utility wares } & \multicolumn{2}{|c|}{ Fine warcs } & \multirow[t]{2}{*}{$\mathrm{N}$} \\
\hline & No. & $\%$ & No. & $\%$ & \\
\hline A (oxidizing) & 7 & 22.6 & - & - & 7 \\
\hline B (reducing) & 7 & 22.6 & 1 & 50.0 & 8 \\
\hline $\mathrm{C}$ & - & - & - & - & 0 \\
\hline D (incompletely & - & - & - & - & 0 \\
\hline E oxidized) & 2 & 6.5 & - & - & 2 \\
\hline $\mathrm{F}$ & 5 & 16.1 & - & - & 5 \\
\hline $\mathrm{G}$ (fired in a reducing & 9 & 29.0 & 1 & 50.0 & 10 \\
\hline $\begin{array}{l}\text { H environment and } \\
\text { cooled in the open } \\
\text { air) }\end{array}$ & 1 & 3.2 & - & - & - \\
\hline \multicolumn{6}{|l|}{ Summary of firing conditions } \\
\hline$\%$ oxidizing & 7 & 22.6 & - & - & 7 \\
\hline$\%$ incomplctely oxidized & 2 & 6.5 & - & - & 2 \\
\hline$\%$ reducing & 7 & 22.6 & 1 & 50.0 & 8 \\
\hline $\begin{array}{l}\% \text { fired in a reducing } \\
\text { environment, cooled in } \\
\text { an oxidizing cnvironment }\end{array}$ & 15 & 48.4 & 1 & 50.0 & 16 \\
\hline Totals & 31 & 100.0 & 2 & 100.0 & 33 \\
\hline
\end{tabular}

\section{TEMPORAL AND CULTURAL AFFILIATIONS}

The analysis of the dccorated ceramic sherds from the Grace Creek \#1 site indicate that there were three temporally distinct occupations or components there, with the principal occupation dating early in the prehistoric Caddo era. These are a ca. A.D. 400-800 late Woodland component, a ca. A.D. 850-1050 early Caddo component with stylistic affiliations to other sites in the Sabine River basin, and a ca. postA.D. 1500-1600 Late Caddo Titus phase occupation.

\section{Woodland Period Occupation}

This occupation dates to the late Woodland period, from ca. A.D. 400-800. Although not apparent in the East Texas archeological record, this was a time of major mound construction and ritual activities in areas along the Red River, including the Crenshaw (Schambach 1982) and Fredericks (Girard 2000) sites. The few sherds of this age found at the site suggests only a limit use during this era, however. By ca. A.D. 850 , the use of the site changed dramatically. 
Table 13. Orifice diameters of plain rim sherds.

\begin{tabular}{|c|c|c|}
\hline Orifice Diameter (in cm) & No. & Percentage \\
\hline 4.0 & 1 & 2.0 \\
\hline 5.0 & 1 & 2.0 \\
\hline 10.0 & 1 & 2.0 \\
\hline 12.0 & 2 & 4.1 \\
\hline 13.0 & 3 & 6.1 \\
\hline 14.0 & 4 & 8.2 \\
\hline 15.0 & $4^{*}$ & 8.2 \\
\hline 16.0 & 7 & 14.3 \\
\hline 17.0 & 1 & 2.0 \\
\hline 18.0 & 8 & 16.3 \\
\hline 20.0 & $9^{*}$ & 18.4 \\
\hline 21.0 & 2 & 4.1 \\
\hline 22.0 & 2 & 4.1 \\
\hline 23.0 & 1 & 2.0 \\
\hline 24.0 & 2 & 4.1 \\
\hline 30.0 & 1 & 2.0 \\
\hline Totals & 49 & 100.0 \\
\hline
\end{tabular}

*one of each orifice diameter group has a drilled suspension hole

Table 14. Plain rim sherd rim and lip profiles.

\begin{tabular}{|c|c|c|}
\hline Rim-Lip Profile & No. & Percentage \\
\hline Direct rim-rounded lip & $58^{*}$ & 66.7 \\
\hline Direct rim-rounded, exterior folded & 3 & 3.4 \\
\hline Direct rim-flat lip & 4 & 4.6 \\
\hline Everted-rounded & 7 & 8.0 \\
\hline Inverted-rounded & $9^{*}$ & 10.3 \\
\hline Unknown rim-rounded lip & 6 & 6.9 \\
\hline Totals & 87 & 100.0 \\
\hline
\end{tabular}

*one rim has a drilled suspension hole 
Table 15. Temper use in the Grace Creek \#1 Site plain wares.

\begin{tabular}{lll}
\hline Temper class & No.* & Percentage \\
\hline grog & 165 & 48.1 \\
grog/sandy paste & 3 & 0.9 \\
grog-bone & 75 & 21.9 \\
grog-hematite & 48 & 14.0 \\
grog-bone-hematite & 24 & 7.0 \\
grog-bone-hematite/sandy paste & 1 & 0.3 \\
bone & 10 & 2.9 \\
sandy paste & 2 & 0.6 \\
no visible temper & 15 & 4.4 \\
& & \\
Summary of sherd temper data: & 316 & 92.1 \\
sherds with grog temper & 110 & 32.1 \\
sherds with bone temper & 73 & 21.3 \\
sherds with hematite temper & 6 & 1.7 \\
sandy paste & & \\
& *based on the detailed analysis of $343(24.5 \%)$ of the 1403 plain sherds in the collection
\end{tabular}

\section{Early Caddo Occupation}

The early Caddo occupation at the Grace Creek \#1 site is substantial, with the site apparently representing a domestic occupation, based on pit and burial features and the devclopment of a substantial midden deposit (see Jones 1957; Story 2000) and a large ceramic assemblage of plain wares ( $\mathrm{n}=89$ rims), decorated utility wares $(n=89$ rims), and decorated fine wares $(n=10$ rims). The range of pottery types identified in the decorated sherd assemblage-including the predominance of Coles Creek Incised, var. Coles Creek, accounting for about $70 \%$ of the decorated rim sherds - as well as other varieties of the type, Beldeau Incised, var. Beldeau, French Fork Incised, var. McNutt, Holly Fine Engraved, Hickory Engraved, Crockett Curvilinear Incised, Pennington Punctated Incised, Davis Incised, Weches Fingernail Impressed, var. Alto and var. Weches, and Dunkin Incised, suggests this occupation dates between ca. A.D. 850-1050, during the early part of the Caddo era in East Texas. In support of this estimated age for the Grace Creek \#1 early Caddo occupation, Girard (2009a:27-28) has developed a relatively detailed ceramic chronology for the early Caddo occupations along the Red River in Northwest Louisiana. It has been noted that "between A.D. 900 and 1050, decorated specimens increased in number, but still constituted only about 10 percent or less of most assemblages. Horizontal incising was common, and distinctive elements associated with Coles Creek Incised, var. Coles Creek (overhanging lines, sometimes with underlying triangular punctations) often occurred. I suspect that the type Weches Fingernail Punctated is a regional variant of this Coles Creek theme. Body sherds with large fingernail punctations (e.g., Kiam Punctated Incised) also appeared. This interval might be the time of initial use of engraved pottery, although percentages were very low" (Girard 2009a:27-28). Girard (2009b:52) suggests there was a period of strong Lower Mississippi Valley Coles Creek influence among Caddo peoples in parts of the Caddo area between ca. A.D. 900-1050, and this influence (and presumably considerable contact) is most notably detected in the character of the ceramic wares from sites such as the Grace Creek \#1 site.

The Caddo occupation at the Grace Creek \#1 site appears to be contemporaneous with the carliest part of the Alto phase component at the George C. Davis site on the Neches River, dating as the latter does from the mid- $9^{\text {th }}$ century A.D. to the mid- $11^{\text {th }}$ century A.D. (cf. Story 2000 ). That site was appar- 
Table 16. Firing conditions in the Grace Creek \#1 site plain ware sherds.

\begin{tabular}{|c|c|c|}
\hline Firing conditions & No. & Percent \\
\hline A (oxidizing) & 16 & 4.7 \\
\hline B (reducing) & 119 & 34.7 \\
\hline $\mathrm{C}$ & 2 & 0.6 \\
\hline D (incompletely & 1 & 0.3 \\
\hline E oxidized) & 10 & 2.9 \\
\hline $\mathrm{F}$ & 98 & 28.6 \\
\hline $\mathrm{G}$ (fired in a reducing & 82 & 23.9 \\
\hline $\begin{array}{l}\text { H environment and } \\
\text { cooled in the open } \\
\text { air) }\end{array}$ & 9 & 2.6 \\
\hline $\mathrm{J}$ & 1 & 0.3 \\
\hline K (sooted, smudged, & 3 & 0.9 \\
\hline $\mathrm{L}$ refired) & 1 & 0.3 \\
\hline $\begin{array}{l}X \text { (both oxidized and } \\
\text { reduccd zoncs in the } \\
\text { paste) }\end{array}$ & 1 & 0.3 \\
\hline Summary of firing conditions & & \\
\hline$\%$ oxidizing & 16 & 4.7 \\
\hline$\%$ incompletely oxidized & 13 & 3.8 \\
\hline$\%$ reducing & 119 & 34.7 \\
\hline $\begin{array}{l}\% \text { fired in a reducing } \\
\text { environment, cooled in } \\
\text { an oxidizing environment }\end{array}$ & 189 & 55.1 \\
\hline $\begin{array}{l}\% \text { irregular or poorly controlled } \\
\text { firing }\end{array}$ & 6 & 1.7 \\
\hline Totals & 343 & 100.0 \\
\hline
\end{tabular}

ently continuously occupied through the end of the $13^{\text {th }}$ century A.D. However, the fine wares and the utility wares found at the Grace Creek \#1 site do not suggest that it is a component of the Alto phase, although such sites have been identified in the Sabine River basin (sce Story 2000:Figure 5), including the Hudnall-Pirtle site mound center (41RK4). Story (2000:20) has pointed out that "components of this phase are no where common even though some of the diagnostics, such as Weches Fingernail Punctated and Holly Fine Engraved, have wide distributions." Such appears to be the case here, because while there are a few sherds of Holly Fine Engraved and Weches Fingernail Impressed in the Grace Creek \#1 site decorated sherds, they do not dominate the decorated sherd assemblages. Coles Creck Incised and other 
horizontal incised vessel sherds dominate the Grace Creek \#I assemblage of decorated sherds. Other Alto phase ceramic types, including Davis Incised, Dunkin Incised, Crockett Curvilinear Incised, Pennington Punctated-Incised, Hickory Engraved, or Duren Neck Banded, are also rare at Grace Creek \#1, as they assuredly are not at the George C. Davis site (Stokes and Woodring 1981:Table 26). For example, Stokes and Woodring (1981:Table 26) note that Holly Fine Engraved vessel sherds and Weches Fingernail Punctated sherds both comprise between $16-41 \%$ of the more than 14,000 decorated sherds from mound and domestic contexts across the site, and incised-punctated Crockett Curvilinear Incised and Pennington Punctated Incised sherds are also fairly well-represented (2-19\% by excavation areas) at this mound center. Only a handful of sherds from the Grace Creek \#I site were identified as coming from either Holly Fine Engraved or Weches Fingernail Impressed/Punctated vessels. Less than 7\% of the sherds at the Grace Creek \#1 site (see Table 1) have incised-punctated decorative elements, few of which resemble in execution either Crockett Curvilinear Incised or Pennington Punctated-Incised vessels.

At best, then, the broad similarities in vessel decorations in both fine wares and utility wares between the Grace Creek \#I site and the well-known George C. Davis site are indicative of contemporaneous Caddo occupations - and perhaps cven a modicum of contact/interaction - but they do not belong to the same Caddo communities, groups, or ceramic traditions, either traditions centered at the George C. Davis site, or others along the Red River in Northwest Louisiana and Southwest Arkansas. Instead, the Grace Creck \#1 site is apparently a component of a local and culturally separate Caddo community in the Sabine River basin, one that is currently taxonomically undefined, that was established around ca. A.D. 850 and whose occupation probably lasted until at least ca. A.D. 1050 locally, but most likely extended to after ca. A.D. 1200 at the major settlements (Bruseth and Perttula 2006; Perttula 201f).

\section{Late Caddo, Titus phase Occupation}

The final Caddo occupation of the Grace Creek \#1 site took place in Late Caddo times, in the latter part of the Titus phase (after ca. A.D. 1500-1600). The Titus phase attribution is based on the identification of two varieties of Ripley Engraved fine ware, the main line ware found in Titus phase contexts in East Texas, along with a number of both Bullard Brushed and Pease Brushed-Incised utility ware sherds; brushed sherds are particularly common in this Titus phase component. The number of recognizable Late Caddo decorated sherds $(n=79)$ at the site also suggests that it was a domestic settlement at this time, though of what kind (i.e., farmstead, hamlet, or small village) is unknown.

\section{CONCLUSIONS}

The detailed analysis of the native-made ceramic sherds from the Grace Creek \#1 site has provided a rare opportunity to re-analyze, and take a new look at, sherds from a previously reported early Caddo site in East Texas (cf. Jones 1957; Story 2000). This reanalysis first disclosed that the assemblage of sherds $(n=1827)$ was much larger than reported by Jones (1957), and the inspection of the decorated sherds indicated that the Grace Creek \#1 site was used during three periods of time: ca. A.D. 400-800, ca. A.D. 850-1050, and after ca. A.D. 1500-1600. As expected from the article written by Jones (1957) on the site, the ca. A.D. 850-1050 early Caddo domestic occupation there was the time of the site's principal prehistoric occupation.

The ceramics that can be attributed to this early Caddo occupation are primarily from vessels that are grog or grog-bone tempered and have been fired in a low oxygen or reducing environment. These vessels were then cooled in the open air, leaving the vessets with exterior and/or interior lighter-colored and oxidized surfaces (usually the exterior surface of plain and decorated vessels). Based on the number of rim sherds $(n=188)$, the vessels in the collected assemblage at the site are equally divided between plain wares $(47 \%)$ and decorated utility wares $(47 \%)$, including jars, bowls, carinated bowls, and bottles, with engraved fine ware vessels represented by only about $5 \%$ of all the rims from the sitc. 
Among the decorated utility wares, by far the most common decorative elements are horizontal incised lines on vessel rim sherds, and these are from several varieties of Coles Creek Incised, particularly var. Coles Creek. Outside of the lower Mississippi Valley, this type is best seen in ca. A.D. 900-1050 Caddo sites in East Texas, Northwest Louisiana, and Southwest Arkansas. Many of these vessels have a distinctive row of impressed triangles below the bottom horizontal incised line, and several other sherds (related to both Coles Creek Incised and Weches Fingernail Impressed) have rows of impressed triangles between horizontal incised lines on vessel rims. Other utility ware types at the Grace Creek \#1 site in early Caddo times include Davis Incised, Dunkin Incised, Bcldcau Inciscd, French Fork Incised, Weches Fingernail Impressed, Crockett Curvilinear Incised, and Pennington Punctated-Incised. Finc wares of the period at the site are represented by a few sherds of Hickory Engraved and Holly Engraved.

As best as can be determined at the present time by this examination of the plain and decorated sherds from the Grace Creek $\# 1$ site in the Gregg County Historical Museum collections, the early Caddo occupation at the Grace Crcek \#1 site on Grace Creek, a southward-flowing tributary to the Sabine River, is contemporaneous with the Alto phase and other taxonomic units defined in the Caddo area. It is clearly not an Alto phase occupation (contra Story [2000]), but instead is suspected to be an early Caddo occupation in a political community of kin-related Caddo pcoples focused around the Hudnall-Pirtle mound center (4IRK4), a few miles to the southeast, and on the opposite side of the Sabine River from the Grace Creek \#1 site.

\section{ACKNOWLEDGEMENTS}

I would like to thank Patti Haskins of the Gregg County Historical Museum for facilitating access to the Grace Creek site materials for analysis in the summcr of 2010. Mark Walters lent his expertise to the ceramic analysis of the plain sherds and miscellaneous clay artifacts, and also took a number of artifact photographs during the course of the work that proved useful in the completion of this article. Lance Trask prepared the sherd illustrations, based on drafts I provided to him.

\section{REFERENCES CITED}

Brown, I. W.

1998 Decorated Pottery of the Lower Mississippi Valley: A Sorting Manual. Mississippi Archaeological Association and Mississippi Department of Archives and History, Jackson.

Bruseth, J. E. and T. K. Perttula

2006 Archeological Investigations at the Hudnall-Pirtle Site (41RK4): An Early Caddo Mound Center in Northeast Texas. Caddo Archeology Journal 15:57-158.

Girard, J. S.

1998 Excavations at the Fredericks Site (16NA2). Regional Archaeology Program, Management Unit 1, Ninth Annual Report. Northwestern State University of Louisiana, Natchitoches.

2000 Excavations at the Fredericks Site (16NA2), Natchitoches Parish, Louisiana. Louisiana Archaeology 24:1-106.

2009a Regional Archaeology Program Management Unit I, Twentieth Annual Report. Northwestern State University of Louisiana, Natchitoches. Report on file with the Louisiana Division of Archaeology, Department of Culture, Recreation and Tourism, Baton Rouge.

$2009 \mathrm{~b}$ Comments on Caddo Origins in Northwest Louisiana. Journal of Northeast Texas Archaeology 31:51-60. 
Jones, B. C.

1957 The Grace Creek Sites, Gregg County, Texas. Bulletin of the Texas Archeological Society 28:198231.

Hoffman, M. P.

1967 Ceramic Pipe Style Chronology Along the Red River Drainage in Southwestern Arkansas. The Arkansas Archeologist 8(1):4-14.

Lee, A.

2007 The Troyville Site: Embankment and River Bank Excavations. Newsletter of the Louisiana Archaeological Society 34(3):5-7.

McGimsey, C. R.

2004 The Gold Mine Site (I6RI13): An AD 825 Ossuary in Northeast Louisiana. Regional Archaeology Program, Management Unit III, 2003/2004 Annual Report, University of Louisiana at Lafayette.

Middlebrook, T.

2010 The Jack Walton Site (41SA135), San Augustine County, Texas. Journal of Northeast Texas Archaeology 33:1-23.

Newell, H. P and A. D. Krieger

1949 The George C. Davis Site, Cherokee County, Texas. Memoir No. 5. Society for American Archaeology, Menasha, Wisconsin.

Perttula, T. K.

1992 "The Caddo Nation": Archaeological \& Ethnohistoric Perspectives. University of Texas Press, Austin.

2011 Analysis of the Ceramic Artifacts from the Boxed Springs Site. In Archaeological and Archaeogeophysical Investigations at an Early Caddo Mound Center in the Sabine River Basin of East Texas, assembled by T. K. Perttula, pp. 47-77. Special Publication No. 15. Friends of Northeast Texas Archaeology, Pittsburg and Austin.

Perttula, T. K. (editor)

2008 Lake Naconiche Archeology, Nacogdoches County, Texas: Results of the Data Recovery Excavations at Five Prehistoric Archeological Sites. 2 Vols. Report of Investigations No. 60. Archeological \& Environmental Consultants, LLC, Austin.

Perttula, T. K. (assembler)

2011 Archaeological and Archaeogeophysical Investigations at an Early Caddo Mound Center in the Sabine River Basin of East Texas. Special Publication No. 15. Friends of Northeast Texas Archacology, Pittsburg and Austin.

Perttula, T. K., M. Walters, and B. Nelson

2010 Caddo Pottery Vessels and Pipes from Sites in the Big Cypress, Sulphur, Neches-Angelina, and Middle Sabine River Basins in the Turner and Johns Collections, Camp, Cass, Cherokee, Harrison, Morris, Titus, and Upshur Counties, Texas and Sabine Parish, Louisiana. Special Publication No. 10. Friends of Northeast Texas Archacology, Pittsburg and Austin.

Phillips, P.

1970 Archaeological Survey in the Lower Yazno Basin, Mississippi, 1949-1955. 2 Parts, Volume 60. Peabody Museum of Archaeology and Ethnology, Harvard University, Cambridge. 
Rolingson, M. A.

1998 Toltec Mounds and Plum Bayou Culture: Mound D Excavations. Research Series 54. Arkansas Archeological Survey, Fayetteville.

Stokes, J. and J. Woodring

1981 Native-Made Artifacts of Clay. In Archeological Investigations at the George C.Davis Site, Cherokee County, Texas: Summers of 1979 and I980, edited by D. A. Story, pp. 135-238. Occasional Papers No. 1. Texas Archeological Research Laboratory, The University of Texas at Austin.

Story, D.A.

1990 Cultural History of the Native Americans. In The Archeology and Bioarcheology of the Gulf Coastal Plain, by D. A. Story, J. A. Guy, B. A. Burnett, M. D.Freeman, J. C. Rose, D. G. Steele, B. W. Olive, and K. J. Reinhard. pp. 163-366. 2 Vols. Research Series No. 38. Arkansas Archeological Survey, Fayetteville.

2000 Introduction. In The George C. Davis Site, Cherokee County, Texas, by H. P. Newell and A. D. Kricger, pp. 1-31. 2nd Edition. Society for American Archaeology, Washington, D.C.

Teltser, P. A.

1993 An Analytic Strategy for Studying Assemblage-Scale Ceramic Variation: A Case Study from Southeast Missouri. American Antiquity 58(3):530-543.

Walters, M., with contributions by T. Middlebrook and T. K. Perttula

2010 Redwine or Pie-Crust Mode Forms in East Texas Caddo Ceramics and Comparisons with Sprocket-Rims of Southwest Arkansas. Caddo Archeology Journal 20:77-128.

Walters, M. and T. K. Perttula

2010 The Holmes Site (41SM282): An East Texas Sitc with Lower Mississippi Valley Ceramic Sherds. Louisiana Archaeology 31:34-42.

Webb, C. H.

1963 The Smithport Landing Site: An Alto Focus Component in DeSoto Parish, Louisiana. Bulletin of the Texas Archeological Society 34:143-187.

Webb, C. H. and R. R. McKinney

1975 Mounds Plantation (16CD12), Caddo Parish, Louisiana. Louisiana Archaeology 2:39-127. 


\section{APPENDIX 1, GRACE CREEK \#2 SITE CERAMICS (41GG34)}

The Grace Creek \#2 site is on an upland ridge projection on the south side of Grace Creek and an old channel of the creek, a tributary to the Sabine River, about $2 \mathrm{~km}$ from the conflucnce of the two streams. Buddy Jones conducted surface collections and limited excavations of the site before it was apparently destroyed by construction of an earthen dike (Jones 1957:203). A single pit feature (Pit B) was documented during the excavations.

Joes indicated that the Grace Creek \#2 site had only seven ceramic sherds in its artifact assemblage, along with one Alba arrow point (Jones 1957:210-212). However, the Gregg County Historical Museum has a collection of 25 sherds from the site that were available for analysis that Jones apparently gathered in 1955 and 1956.

The 25 shcrds include 18 plain rim, body, and base sherds; the four rim sherds are part of a single plain carinated bowl with a direct rim and a flat lip. The plain sherds are tempered with grog $(50 \%$ of the sherds analyzed in detail), crushed bone (33\%), and bone and grog $(17 \%)$. The majority of the sherds are from vessels fired in a low oxygen or reducing environment $(83 \%)$, although a significant number of them $(60 \%)$ were apparently pulled from the fire and left to cool in the open air, leaving one or both surfaces with a lighter oxidized color. One plain body sherd was from a vessel that was fired and cooled in a high oxygen environment.

The seven decorated sherds from the Grace Creek \#2 site include four rims and three body sherds. They are tempered with grog $(75 \%)$ and bone-grog $(25 \%)$. They are from vessels fired in a low oxygen or reducing environment, then apparently pulled from the fire and left to cool in the open air, leaving one or both surfaces with a lighter oxidized color.

All rim sherds have incised decorations, three with between two and more than eight horizontal incised lines; the incised lines on one rim are overhanging (Figure A1.1), suggesting it is from a Coles Creek Incised vessel. The other incised rim sherd is from a carinated bowl; the rim is decorated with vertical incised lines around the rim panel.

Two of the body sheds have punctated decorations, including one sherd with rows of tool punctations and the other with randomly or freely-placed fingernail punctations. The remaining body sherd has closely spaced parallel incised lines.

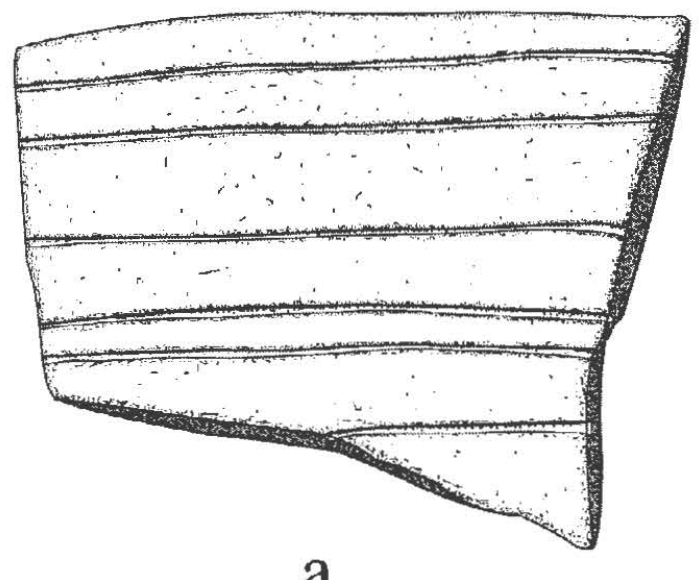

a

Figure A1.1. Horizontal incised rim sherd from the Grace Creek \#2 site. Drawing by Lance Trask.

The ceramic assemblage, along with the one arrow point reported by Jones (1957), from the Grace Creek \#2 site, is likely contemporaneous with the Grace Creek \#1 site. That site appears to have been occupied ca. A.D. 850-1000, early in the Caddo era (Perttula 2011:69). 


\section{APPENDIX \#2, 41GG51 (GC 85) CERAMICS}

Site 4IGG51 is a prehistoric site along Hawkins Creek in the Sabine River basin in East Texas. This site reportedly had a pit with a flexed hurial excavated by Buddy Calvin Jones in the 1950s. In East Texas, flexed burials tend to be found in Woodland period contexts, rather than in post-ca. A.D. 800-850 Caddo sites, although the age of the burial at this site has not been established. There were 13 plain and decorated sherds from the fill of the flexed burial pit.

The eight plain sherds in the small assemblage are grog-tempered, but are not from thick-walled or coarse paste Williams Plain vessels, usually considered a (but not an exclusively) reliable indicator of a Woodland period component in this part of East Texas. The sherds are from vessels fired and cooled in an oxidizing environment ( $20 \%$ of the sherds analyzed in detail); incompletely oxidized (20\%); and fired in a reducing environment $(60 \%)$.

The five decorated sherds are from grog $(67 \%)$ and grog-hematite tempered $(33 \%)$ vessels. All are from vessels fired in a low oxygen or reducing environment, then pulled from the fire and left to cool in the open air, leaving one or both surfaces with a lighter oxidized color. One of the decorated body sherds has freely-placed tool punctations, while the other four have incised decorative elements. These include a rim with opposed incised lines (Figure A2.1a), possibly from a Dunkin Incised jar or barrel-shaped bowl (cf. Suhm and Jelks 1962:Plate 19a), and another rim with two horizontal incised lines encircling the vessel, and a series of short diagonal incised lines between the upper and lower horizontal incised lines (Figure A2.1b). The two incised body sherds have closely to very closely-spaced parallel incised lines (5-12+ lines), possibly from Davis Incised or Coles Creek Incised vessels.

Although the sherd assemblage is small from 4 lGG5I, there is nothing in the ceramic assemblage that would indicate the site dates from the Woodland period or that the flexed burial excavated by Jones was a Woodland period interment. Rather, the 41GG5I ceramics in the Buddy Jones Collection at the Gregg County Historical Museum suggest it was occupied in the Formative or Early Caddo periods (ca. A.D. 800-1200); the flexed burial apparently dates to that era. ${ }^{1}$
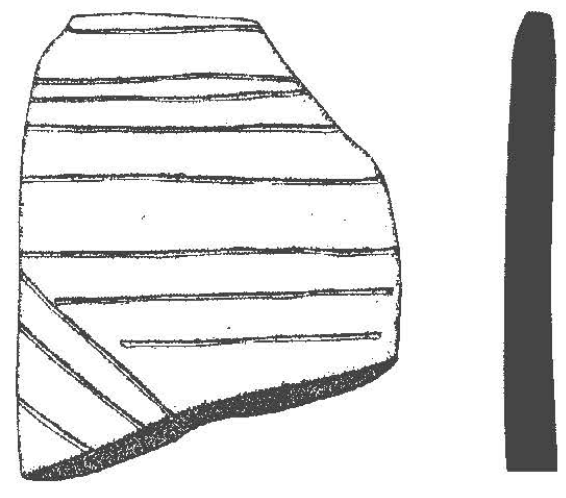

a

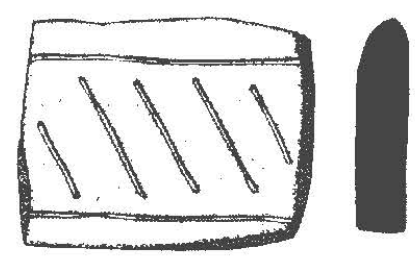

b

Figure A2.1. Incised rim sherds from 41 GG51.

\section{END NOTE}

1. Site documentation efforts in the mid-1990s by Bo Nelson also indicate that 41 GG.51 had a Late Caddo Titus phase cemetery with more than 20 burials. The site trinomial was assigned at that time, and Nelson was unaware of the fact that Buddy Jones had worked at the site more than 40 years either. Jones did not obtain a site trinomial for the site while he was working there.

\section{REFERENCES CITED}

Suhm, D. A. and E. B. Jelks (editors)

1962 Handbook of Texas Archeology: Type Descriptions. Special Publication No. 1, Texas Archeological Society, and Bulletin No. 4, Texas Memorial Museum, Austin. 


\section{APPENDIX 3, BOATSTONE SITE CERAMICS (GC 83)}

The Boatstone site, on North Hawkins Creek in Gregg County, Texas, has a small assemblage of ceramic sherds, several of which appear to be from at least one Williams Plain vessels. The sherds were apparently picked up in a surface collection by Buddy Calvin Jones in 1955, when he also collected a polished boatstone fragment.

There are 21 sherds in the collection, including 18 plain sherds and three decorated sherds. Half of the plain sherds are body and base sherds from two extremely thick and grog-tempered Williams Plain vessels. The body sherds range from 9.0-14.4 mm in thickness, and the thickness of the Williams Plain base sherds range from $28.20-31.26 \mathrm{~mm}$ (Figure A3.1). The other plain sherds include a rim (direct with a rounded lip), a bone-grog-tempered base sherd, and seven body sherds from grog and grog-bone-tempered vessels. These sherds are all less than $9-10 \mathrm{~mm}$ in thickness.

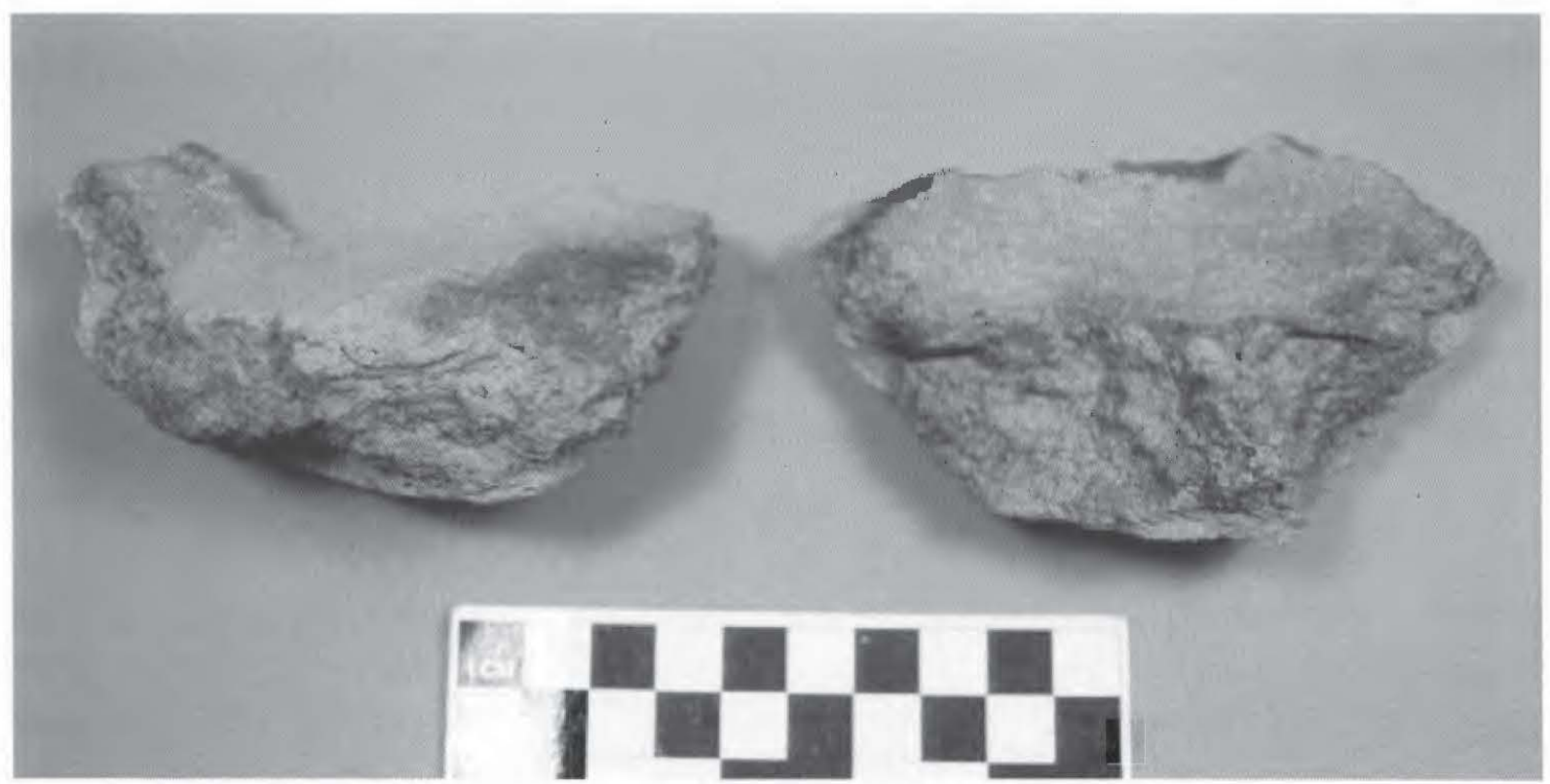

Figure A3.1. Two Williams Plain base sherds from the Boatstone site.

Two of the decorated sherds may be from the same occupation, although it is not known if they are associated temporally with the Williams Plain vessel fragments. One of these is a grog-tempered rim (direct with a rounded lip) with an incised line on the interior vessel surface; this decorative treatment is not common in East Texas vessels, but has been documented in many Caddo ceramic assemblages, nonetheless. The other probably associated decorated sherd is also grog-tempered. It has a single horizontal incised line on the vessel body, just above the body-base juncture.

The third decorated sherd from the Boatstone site is a body sherd with overlapping brushed marks and incised lines. This particular sherd is likely from a post-A.D. 1200-1250 use of the site, because brushed ceramic vessels are not common in East Texas Caddo sites until after that time.

In sum, it is possible that the ceramics from the Boatstone site are associated primarily with a late Woodland occupation, where thick Williams Plain vessels and much thinner plain wares were both being made and used by Woodland peoples. The two incised sherds may or may not belong together with all the plain wares, and it is possible that they are associated with a second, and Caddo, occupation that dates sometime after ca. A.D. 850. The final use of the site in prehistoric times is marked by a post-A.D. 12001250 brushed-incised sherd. 